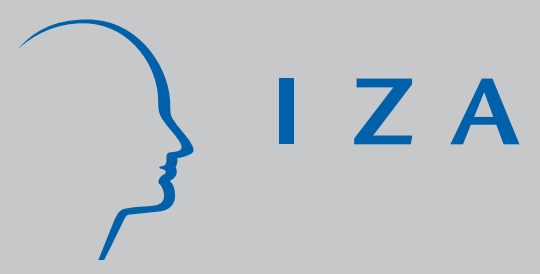

IZADP No. 2889

Should Market Liberalization precede Democracy? Causal Relations between Political Preferences and Development

Pauline Grosj ean

Claudia Senik

J une 2007 


\title{
Should Market Liberalization Precede Democracy? Causal Relations between Political Preferences and Development
}

\author{
Pauline Grosjean \\ European Bank for Reconstruction and Development \\ Claudia Senik \\ Paris School of Economics, University Paris-IV Sorbonne, \\ IUF and IZA
}

\author{
Discussion Paper No. 2889 \\ June 2007
}

IZA

P.O. Box 7240

53072 Bonn

Germany

Phone: +49-228-3894-0
Fax: +49-228-3894-180
E-mail: iza@iza.org

Any opinions expressed here are those of the author(s) and not those of the institute. Research disseminated by IZA may include views on policy, but the institute itself takes no institutional policy positions.

The Institute for the Study of Labor (IZA) in Bonn is a local and virtual international research center and a place of communication between science, politics and business. IZA is an independent nonprofit company supported by Deutsche Post World Net. The center is associated with the University of Bonn and offers a stimulating research environment through its research networks, research support, and visitors and doctoral programs. IZA engages in (i) original and internationally competitive research in all fields of labor economics, (ii) development of policy concepts, and (iii) dissemination of research results and concepts to the interested public.

IZA Discussion Papers often represent preliminary work and are circulated to encourage discussion. Citation of such a paper should account for its provisional character. A revised version may be available directly from the author. 


\section{ABSTRACT \\ Should Market Liberalization Precede Democracy? Causal Relations between Political Preferences and Development ${ }^{*}$}

This paper is dedicated to the relation between market development and democracy. We distinguish contexts and preferences and ask whether it is true that the demand for democracy only emerges after a certain degree of market development is reached, and whether, conversely, democratization is likely to be an obstacle to the acceptation of market liberalization. Our study hinges on a new survey rich in attitudinal variables: the Life in Transition Survey (LITS) conducted in 2006 by the European Bank for Reconstruction and Development and the World Bank, in 28 post-Transition countries. Our identification strategy consists in relying on the specific situation of frontier-zones. We find that democracy enhances the support for market development whereas the reverse is not true. Hence, the relativist argument according to which the preference for democracy is an endogenous byproduct of market development is not supported by our data.

JEL Classification: H1, H5, P2, P3, P5, O1, O12, O57

Keywords: market and democracy, sequencing of development, transition economies, attitudinal variables, cross-country survey

Corresponding author:

Claudia Senik

PSE, ENS

48, bd Jourdan

75014 Paris

France

E-mail: senik@pse.ens.fr

\footnotetext{
* We thank participants in the PSE Public Policy and Labour Market seminar, in the Toulouse Development seminar and at the EBRD lunch seminar. We are grateful to Esther Duflo for her helpful suggestions. All errors are ours. This research has benefited from the support of the CEPREMAP.
} 


\section{Introduction}

One of the unexpected side-effects of China's spectacular emergence is the diffusion of a new conventional wisdom concerning the sequencing of political and economic reforms in developing countries. Essentially, the idea is that early democratization can be harmful. The continued hold of the Chinese Communist Party over political power is taken to be a positive ingredient in the construction of a viable market economy, as opposed to the erratic reform path experienced by Central and European countries of the former socialist block, which predominantly chose rapid economic and political liberalization in the 1990's (Dewatripont and Roland, 1992; Godoy and Stiglitz, 2006; Roland and Verdier, 2003). Another example is Latin America, where pervasive economic crises seem to illustrate the danger that democracy can be an obstacle to the development of the market when leaders have to impose unpopular reforms while being responsible in front of their constituencies. It follows that the optimal route is to develop market institutions in a first stage of development, and consider democratization at a latter stage.

Pushing the argument one step further, some authors have argued that the desire for political freedom and democratic institutions does not arise until countries reach a certain degree of material comfort and market liberalization (Lipset, 1959; Miller et al. 1996). Hence, the argument goes, not only is it preferable to postpone democracy to advanced stages of a country’s economic development, but this sequence also meets citizens’ preferences.

Some observers may find it difficult to reconcile this relativist statement with the recent vivid public demonstrations in favor of democratization in countries of the Commonwealth of Independent States (CIS), e.g. Belarus, Georgia, Ukraine, and in China. In terms of scientific evidence, the empirical literature devoted to the relationship between market and democracy 
remains rather inconclusive. Most studies are unable to draw a clear direction of causality because of the interdependent dynamics followed by the two variables along the history of any given country. Hence, in spite of the strong dynamism of this research field, the scientific consensus on these issues is still in the making.

This paper tries to contribute to the understanding of the relationship between political preferences and development. We exploit a new set of micro evidence from an original survey of 28 Transition economies, the Life in Transition Survey, which was implemented in summer $2006^{3}$.

We first try to isolate the causal relation running from actual democratization to the demand for market liberalization. Our empirical identification strategy relies on the specificities of frontier-zones. Our main assumption is that people who live in an integrated frontier-zone share the same experience of the market and, often, the same historically inherited "cultural attitudes" towards the market and democracy, on both sides of the frontier. This is particularly plausible for the (often artificial) frontiers of the former USSR and in some formerly integrated regions such as the Ottoman Empire or the Austro-Hungarian Empire. This assumption is tantamount to keeping constant the usually omitted variables that bias any estimation of the relation between market development and the support to democracy.

Reciprocally, we try to assess the relation that runs from actual market development to popular demand for democracy. Here, we exploit within-country regional variations. We rely on the fact that the degree of market development is notoriously different across regions of the survey; whereas people who live in the same country share a common experience of democracy. Hence, we regress the preference for democracy on an index of regional market development, reflecting the share of the modern sector of the economy, which is composed of private and smaller size firms. We also compare the support to democracy of the various frontier-zones inside a given country, on the grounds that market development at borders are partly exogenous, as it is influenced by the neighbouring region's market development.

The main result of this paper is that democracy appears to generate some popular support for the market, while economic liberalization does not clearly raise the support for democracy.

\footnotetext{
${ }^{3}$ See EBRD, Life in Transition, a Survey of People's Experiences and Attitudes, May 2007.
} 
To be sure, this finding only suggests that democracy increases the subjective support to the market; it does not mean that democracy does not complicate the task of reformers, with the risk of impeding market liberalization. Our results also cast doubt on the idea that democracy would naturally emerge as a by-product of capitalism. Even if the demand for democracy increases with individual income, market liberalization as such does not seem to be sufficient to trigger the demand for democracy. A minima, the take-home message of the paper is that one cannot advocate the preferences of citizens to postpone the construction of democratic institutions.

Section 2 discusses the background literature in the reciprocal linkages between economic and political liberalization. Section 3 presents the identification strategies. Section 4 presents the data and Section 5 discusses the results. Section 6 concludes.

\section{Background}

The conventional wisdom concerning the linkages between political and economic systems has changed over time. While the early XIXth century was predominantly skeptical about the compatibility between democracy and capitalism (see J.S. Mill or K. Marx ${ }^{4}$ ), today, the consensus is that development leads to both a market economy and to political democracy ${ }^{5}$ with anteriority of the market. The idea that "modern democracy is a by-product of the capitalist process” ${ }^{\prime 6}$ dates back to Toqueville (1839), who stressed that market development is conducive to democracy because it provides the "social space within which individuals, groups and entire institutional complexes can develop independent of state control"7 . Lipset (1959) claims that: "industrialization, urbanization, high educational standards and a steady increase in the overall wealth of society [are] a basic condition sustaining democracy”.

Historically, market economies have existed both in the context of democracy and autocratic regimes, but there is no example of a socialist economy within a democratic regime. This

4 Mill, John Stuart. Considerations on Representative Government. In Utilitarianism, Liberty, and Representative Government, ed. H. B. Acton. London: Dent, 1860. Karl Marx (1867) Capital, Vol. 1 A Critique of Political Economy, ed. Penguin Classique London, 1990.

${ }^{5}$ Hence the concept of the "End of History” (Fukuyama 1992 ).

${ }^{6}$ J.A. Schumpeter, Capitalism, Socialism and Democracy (New York, Harper and Bros., 1942).

${ }^{7}$ A. de Toqueville (1839), Democracy in America, vol. 2 (New York : Vintage :1945). 
observation lies at the foundation of a certain "instrumental” view of political regimes. In the context of the political economy of Transition (Aslund et al., 2001; Dewatripont and Roland, 1992; Roland, 2001; Roland and Verdier, 2003), researchers have focused on the question of how to overcome the political opposition to reforms, and in particular the opposition to economic liberalization. This literature discusses the relative pros and cons of democracy versus authoritarianism from the point of view of facilitating economic reforms and growth. Here, the causality runs from the political regime to the development of the market.

Beyond these theoretical models, what can we learn from empirical studies? To date, the existing empirical literature does not offer many reliable clear-cut results. Many studies focus on the aggregate relationship between democracy or economic liberalization and economic growth. Concerning the relation running from political liberalization to growth, Barro (1990) suggests that the relationship between GDP and democracy is curvilinear and Minier (2001) finds that the probability that a democratic movement emerges in an authoritarian regime is increasing in income per capita up to a level of approximately US\$5000. However, these results are contradicted by Przeworski (2004), who finds that transition from authoritarian regime to democracy is not influenced by income levels, once initial conditions are controlled for $^{8}$. Przeworski and Limongi (1993) review 18 studies and 21 findings concerning the impact of political systems on growth, among which eight are in favor of democracy, eight in favor of authoritarianism and five conclude to no difference. As underlined by Persson and Tabellini (2007b), "the findings are essentially all over the place" with regards to whether democracy shapes economic development (see also, among many, Barro, 1990; Burkhart and Lewis-Beck, 1994; Helliwel, 1994; Leblang, 1997; Przeworski, 2004).

The study of the reverse causality is similarly unconvincing and Przeworski and Limongi (1993) argue that most of these empirical studies suffer from a simultaneity bias. Evidence based on cross-section aggregate data suggests that education and income are the strongest channels towards democracy (La Porta et al., 1999). However, in two related papers, Acemoglu, Johnson, Robinson and Yared (2004a, 2004b) invalidate this finding by showing that the impact of education and income becomes insignificant once within-country variation

\footnotetext{
${ }^{8}$ Przeworski argues that the observed relationship between national income and democratic regimes is an artefact; it is due almost exclusively to the higher durability of any political regime under a higher national income. Hence what is observed in richer countries is not more frequent transitions to democracy but more durable democratic regimes.
} 
and endogeneity of income are taken into account. The authors conclude that cross-section correlations between democracy and education or income are due to an omitted variable bias. This omitted variable, they suggest, consists of the initial institutions that have presided over the country's development (Acemoglu, Johnson and Robinson, 2001). This problem of omitted variable is pervasive in this entire literature.

Some authors have tried to overcome this obstacle using matching, propensity scores and differences in differences methods, exploiting both the cross-country and time series variations in aggregate datasets. Persson and Tabelini (2007a) show that democratic regimes have an important impact on growth but that this relation is conditional on the heterogeneous characteristics of the countries under study. Persson and Tabellini (2007b) show that longer time spans of democracy are a factor of economic development. Persson and Tabellini (2006) suggest that some forms of democracy (presidential) are more development friendly than others (parliamentary) ${ }^{2}$. Rodrick and Wacziarg (2005) find that democratic transitions exert a positive impact on growth in the short run, especially in the poorest countries; it also reduces economic volatility. Other papers, e.g. Sachs and Werner (1995) or Wacziarg and Welch (2003) have tried to elucidate the relation from economic liberalization to growth.

A few papers address directly the question of the interplay between democratization and economic liberalization using aggregate data. Among those, Giavazzi and Tabellini (2005) find that both kinds of reforms have mutual feedbacks on one another, although causality is more likely to run from democratization to economic liberalization. However, they conclude to the superiority of a sequencing based on market liberalization first, from the point of view of growth: "Countries that first liberalize and then become democracies do much better than countries that pursue the opposite sequence”.

Another set of studies has focused on the support for democracy and market economy based on individual data. Surveys try to confirm the predictions that individuals who support a free market economy are more likely to embrace democratic principles (Mc Intosh et al., 1994). This can be because it is in the best self-interest of the wealthiest individuals to support democracy: as they benefit from market development, they seek political representation to protect their newfound economic opportunities. Alternatively, attitudes towards the market can be determined by the political socialization of individuals (Citrin et al, 1990; Easton, 1965). With the exception of Finifter and Mickiewicz (1992), most studies related to Central 
and Eastern Europe find evidence that the support for democratic institutions is highest among the better educated urban residents (Brym, 1996; Mason, 1995; Mc Intosh et al. 1992; Miller et al. 1994 and 1996;) and those most satisfied with the performance of the economy (Mishler and Rose, 1994). However, most studies based on individual data suffer from an identification problem. This is contained in the very idea of the modernization theory that the same development dynamics favor both democracy and market development. Assessing the direction of causality between the advancement of economic freedom and the degree of political freedom appears to be an almost impossible exercise in the absence of a valid exogenous instrument, which needs to be traced back as far as legal or colonial origins (Acemoglu et al.., 2001).

In this paper, we try to overcome this simultaneity bias. We do not pretend to explain the long run causality between democracy and market development; instead we restrict our interest to the short run causality running from the state of market development to the demand for democracy, and, conversely, from political democracy to the support to the market. We ask whether it is true that the demand for democracy only emerges after a certain degree of market development is reached, and whether, conversely, democratization is more likely to be an obstacle or an ingredient to citizens' support to market liberalization.

\section{Identification strategy}

In order to discern the direction of causality between market and democracy, one would ideally need to rely on a situation in which one variable is exogenously "frozen" while the other randomly takes different values across countries. Of course, in the real world there are many reasons why this ideal setting could never exist. On the contrary it is obvious that market liberalization and democracy are processes that follow highly intertwined dynamic evolutions and depend on countries' historical background.

Even in the case of Transition countries, where democracy and the market have been both abolished by the communist experience, the development and the popular support to these institutions have evolved in parallel since 1989, probably under the influence of common factors. As an illustration, Figure 1 shows the strong general cross-country relation between the average support to the market and the average support to democracy in the 28 countries 
covered by the Life in Transition Survey. Regional differences are also visible. In particular, countries of Central and Eastern Europe and the Baltics, which are both the closest to a free market and a full-blown democracy, are the most supportive of the two processes. Identical factors, such as the perspective of accessing the European Union, are likely to have driven the two attitudes simultaneously.

Figure 1. Support for the Market and for Democracy ${ }^{9}$

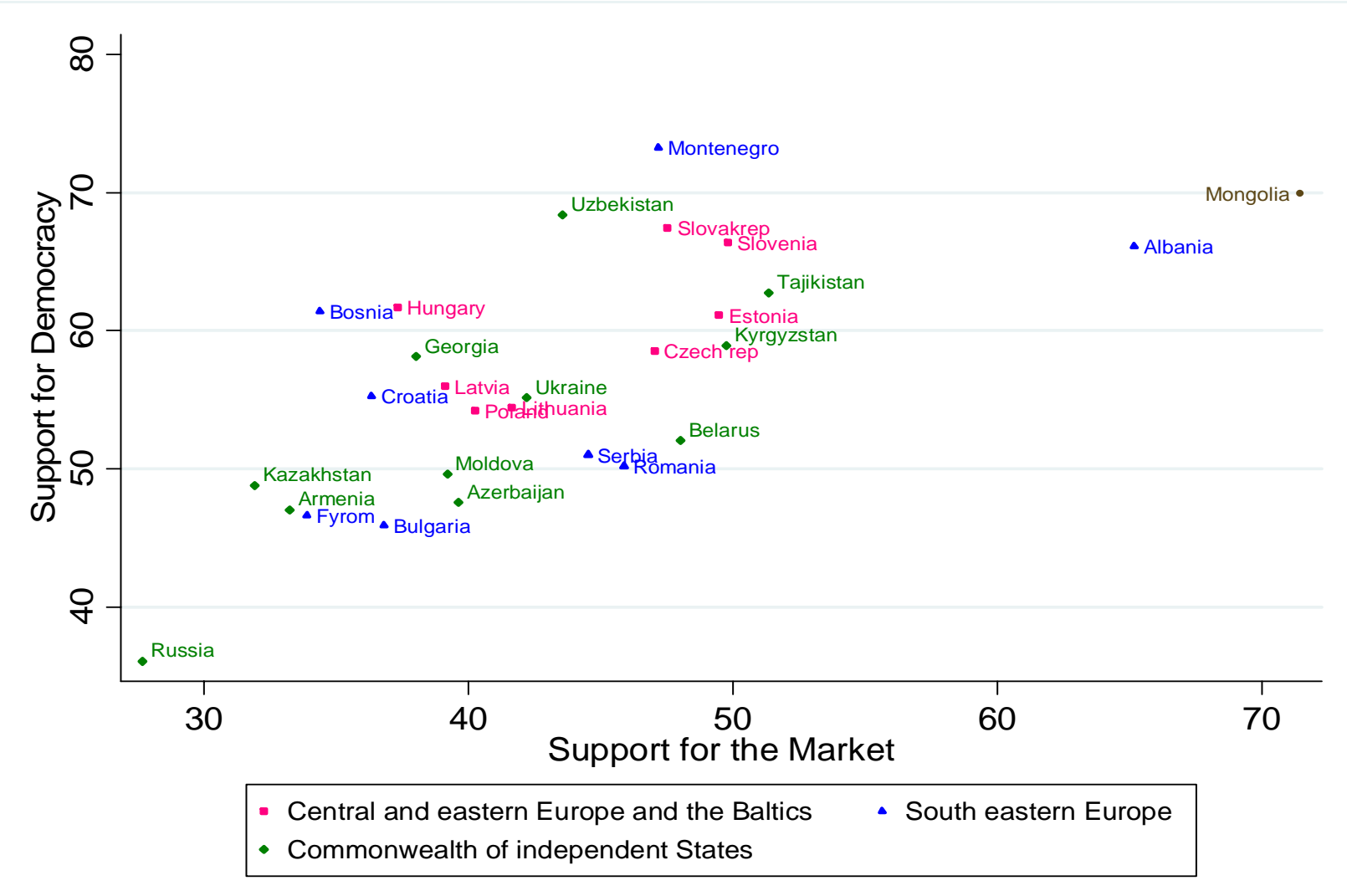

Obviously, using the pooled cross-section data of the LITS survey and running a naive regression of the support to democracy on an index of market development, or of the support to the market on a democratic index, would run into serious identification problems. The

\footnotetext{
${ }^{9}$ Percentage of respondents who chose the market (respectively democracy) as the best system of organisation of the economic (respectively political) system, see section 4.
} 
relation put in evidence would not readily be interpretable in terms of causality as it would be subject to the influence of omitted variables affecting both market development and democracy. We propose two different identification strategies in order to isolate the direction of causality from market development to the support to democracy and vice-versa.

\subsection{Democracy and the demand for the market}

Is a higher degree of democracy an obstacle to reform, or does it increase the support to market development? In order to address this question, we need to overcome the problem that people's support to the market may be due both to the degree of democracy and to the degree of market development itself, both variables being likely to develop at a parallel pace. More generally, it can be suspected that common "cultural factors" influence the national attitudes towards both the market and democracy.

In other words, one would like to estimate the naive equation (1):

Support for market $_{i j}=a_{0}+a_{1}$ degree of development of democracy ${ }_{j}+a_{2} X_{i j}+a_{3} C_{j}+u_{i}$

but suspects that the true relation is (1'):

Support for market ${ }_{\mathrm{ij}}=\mathrm{a}_{0}+\mathrm{a}_{1}$ degree of development of democracy $\mathrm{j}_{\mathrm{j}}+\mathrm{a}_{2}$ degree of development of market $_{j}+\mathrm{a}_{3}$ cultural factors ${ }_{j}+\mathrm{a}_{4} \mathrm{X}_{\mathrm{ij}}+\mathrm{a}_{5} \mathrm{C}_{\mathrm{j}}+\mathrm{u}_{\mathrm{i}}$

where $X_{i j}$ stands for socio-demographic characteristics of the respondent $i$ in country $j, C_{j}$ is a vector of country dummies and $\mathrm{u}_{\mathrm{i}}$ the error term.

Our strategy consists in trying to find a way of keeping the second and third terms of equation (1') constant. As our analysis is based on individual data, we need to find people who, in an exogenous way, are exposed to different levels of democracy but to the same degree of market development and who share the same "culture" regarding the politico-economic system.

The idea is to match observations in frontier-zones. We make use of the spatial integration of regions which stand on both sides of a given frontier, at the immediate proximity of the border. We assume that people who live in open frontier-zones share the same culture and the 
same perception of market development even though they live on both sides of the frontier.

This relies on three types of arguments. The first one is the well-documented high level of interregional trade in frontier zones. Secondly, it is well known that in such regions, when it is possible, people do not hesitate to cross the frontier to go working, to buy their daily shopping, or to buy cheaper appliances and cars, hence regional integration is a fact of their everyday life, which certainly influences their perception of the market. Third, in the specific case of the 21 former Soviet Republics, regional integration was a hard fact until the early 1990's: under the socialist system, the economy of the Soviet Republics was submitted to the centralized organization of material resources by the Soviet plan based in Moscow. Many countries, in particular in Central Asia and the Caucasus, have inherited from the Soviet Union an integrated network of infrastructures, which is a positive factor of trade and regional integration (Broadman, 2005). We thus assume that inhabitants of certain frontierzones share the same experience of the market even when they live in different countries with different political institutions.

Clearly, the validity of our assumption relies on the level of market integration across the borders of the surveyed countries. We thus distinguish open frontiers from those that are closed or restricted because of political conflicts or geographical obstacles. We also check that the degree of market development is more similar in adjacent frontier-zones than it is in pairs of adjacent countries.

Market integration at frontier-zones is useful to eliminate the risk that the support to the market that is measured reflects the actual development of the market. What about the “cultural” omitted variable? A first element is that the citizens of the former Socialist block, and in particular of the Soviet Union, have been living for 45 to 70 years in a common political system marked by strong official ideological values concerning the market. Hence, we can assume that they share a common heritage in terms of attitudes towards the market (Alesina and Fuchs-Schundeln, 2005). Beyond this remark, we rely on the fact that current frontiers of many transition countries, especially countries of the CIS, are more or less artificial divisions of formerly integrated jurisdictions, whose citizens have developed common attitudes concerning both market development and political freedom (e.g. the Austro-Hungarian empire, the Ottoman Empire, etc.). The very idea of "culture” and more specifically "national culture" is that countries' past experience continues to exert some 
effects in the long run ${ }^{10}$. We thus rely on the idea that citizens of countries which have belonged to formerly highly integrated zones share a common culture, i.e. common inherited general attitudes towards the market and democracy.

There are some subsets of Transition countries in which this assumption is particularly appealing. Countries that have belonged to the Ottoman Empire (Albania, Armenia, Bosnia, Bulgaria, Macedonia, Montenegro, Romania and Serbia) have developed under the same rule for several centuries (1299-1922). The same can be said about countries of the AustroHungarian Empire (Croatia, Czech Republic, Hungary, Slovak Republic and Slovenia, 18671918), countries of the former Polish Empire (which included Poland, Ukraine, Lithuania, Belarus and parts of Russia, 1569-1795), countries of the USSR (1922-1991), or countries of the Former Yugoslavia (Bosnia, Croatia, Macedonia, Montenegro, Serbia and Slovenia) who shared the same rule for several decades (1918-1991). We thus retain these cultural grouping in order to deal with the potential impact of cultural factors on the demand for democracy.

In the dataset, we identify frontiers-zones with quasi-adjacent Primary Sample Units (PSU) of the survey located on both sides of the frontier (less than $30 \mathrm{~km}$ from each other). For each couple of countries corresponding to a given frontier, we use the democracy score established by Freedom House Nations in Transit 2006 (Freedom House, 2006a). In another specification, we use a dummy variable that indicates which of the two countries is "more democratic", according to this ranking.

Our test thus consists, for all pairs of observations at frontier zones, in regressing individual support to the market on this index of democratic development, controlling for frontier zone dummies and other socio-demographic controls. The assumptions of (i) market integration and (ii) common culture at the frontier between two formerly integrated countries mean that the third and fourth terms of equation (1') are constant and hence need not be included in the regression. We thus run the following regression on the sub-samples of frontier zones:

Support for market $_{i j k}=a_{0}+a_{1}$ Democracy Level $_{j}+a_{4} X_{i}+a_{5} Z_{k}+u_{i}$

${ }^{10}$ In Bisin and Verdier (2000) or Fernandez and Fogli (2005), culture can be defined as long term inertia in preferences. 
where Democracy Level $\mathrm{j}$ corresponds to the democracy score of country $\mathrm{j}, \mathrm{X}_{\mathrm{i}}$ stands for socio-demographic characteristics of respondent $\mathrm{i}, \mathrm{Z}_{\mathrm{k}}$ is a vector of frontier zone dummies and $u_{i}$ the error term. In an alternative specification, we run the same regression on a dummy variable indicating whether the country of residence of an individual is more democratic (or not) than the adjacent country.

\subsection{Demand for democracy}

In order to identify the determinants of the demand for democracy, we need to overcome the symmetrical problem, i.e. to isolate the causation running from market liberalization to the support for democracy, avoiding the contamination of the actual degree of democracy already reached and the influence of "cultural factors", i.e. keeping the second and third terms of equation (2) constant.

Support for democracy ${ }_{\mathrm{ij}}=\mathrm{b}_{0}+\mathrm{b}_{1}$ degree of development of market $\mathrm{j}_{\mathrm{j}}+\mathrm{b}_{2}$ degree of development of democracy ${ }_{j}+b_{3}$ cultural factors ${ }_{j}+b_{4} X_{i j}+b_{5} C_{j}+u_{i}$

Where $\mathrm{Cj}$ is a vector of country dummies.

Here, we hinge both on frontier-zones and on regional and national variations. We rely on the fact that political institutions (and "culture”) are by definition the same in a given country, whereas market development is highly uneven across the various regions of a given country (Zhuravskaia, 2006; EBRD, 2006). We thus build indices of market liberalization at the regional level, and match individuals from the same country who live in regions that experience unequal degrees of market development. As explained in section 4.3, the constructed "industrial liberalization score" reflects the regional development of private, small and medium enterprises and the formal sector, which are characteristics of market development.

We thus estimate the following equation:

Support for democracy $_{\mathrm{ijr}}=\mathrm{b}_{0}+\mathrm{b}_{1}$ degree of development of regional market $\mathrm{jr}_{\mathrm{r}}+\mathrm{b}_{4} \mathrm{X}_{\mathrm{ij}}+\mathrm{b}_{5} \mathrm{C}_{\mathrm{j}}$ $+\mathrm{u}_{\mathrm{i}}$

Where index r refers to the administrative regions of country j.

This strategy relies on the admittedly strong assumption that the uneven development of 
the market across regions of a country is not due to some regional variable that would also influence the attitudes of the inhabitants of the region towards democracy. In order to lift this assumption, we use two strategies. First of all, we control for the type of residence of respondents (metropolitan, urban or rural areas). Second, we again rely on borders' specificities. We assume that in the context of high regional economic integration at borders, the level of market development is strongly influenced by that of the adjacent country. Hence even inside a given country, we assume that market development at the borders vary in a way that is partly exogenous to citizens' preferences for politico-economic values. We thus match individuals of the same country, who live in different frontier-zones, and we regress individual support for democracy on the level of market development in the different frontierzones. To go one step further, in an alternative specification, we use as a proxy for market development in the frontier zone $z j$ of country $j$ the industrial liberalization score of the adjacent frontier-zone $z k$ across the border, in country $k$. We thus estimate the following regressions:

Support for democracy ${ }_{i j k}=b_{0}+b_{1}$ degree of development of regional market ${ }_{\mathrm{zl}}+\mathrm{b}_{4} \mathrm{X}_{\mathrm{ij}}+\mathrm{b}_{5} \mathrm{C}_{\mathrm{j}}$ $+\mathrm{u}_{\mathrm{i}}$

With $\mathrm{l}=\mathrm{j}, \mathrm{k}$, and where $\mathrm{z}$ refers to the frontier-zone of, alternatively, country $\mathrm{j}$ and $\mathrm{k}$.

Of course, even using these identifications strategies, we do not pretend to escape the influence of long term determinants of economic and political development. Neutralizing these long term trends would imply finding an instrument that could approximate the exogenous ultimate origin of these differences. This limits the validity of our conclusions to short term relevance.

\section{Data}

Our study hinges on the Life in Transition Survey (LITS), a survey conducted by the European Bank for Reconstruction and Development and the World Bank in 2006, in 28 postTransition countries and Turkey ${ }^{11}$. Respondents to the survey were drawn randomly, using a two stage sampling method, with census enumeration areas as primary sampling units, and

\footnotetext{
11 Turkmenistan was not included in the survey. We exclude Turkey from our sample, because of its very specific political situation.
} 
households as secondary sampling units. The survey includes 1000 observations per country, for a total of 29000 observations. The sample of respondents is equally balanced in terms of gender, but is biased in favor of elder people: the age of the respondents varies from 17 to 97 years old, with a means of 46 years old. All descriptive statistics are presented in the Annex.

\subsection{The support to the market and to democracy}

The support for the market is analyzed using the following question:

Q3.10. with which one of the following statements do you agree most:

- A market economy is preferable to any other form of economic system.

- Under some circumstances, a planned economy may be preferable to a market economy.

- For people like me, it does not matter whether the economic system is organized as a market economy or as a planned economy.

We analyze the probability to choose any of the three modalities of questions q3.10.

Concerning the support for democracy, we analyze the probability to choose either modalities of question Q.3.11: with which one of the following statements do you agree most:

- Democracy is preferable to any other form of political system.

- Under some circumstances, an authoritarian government may be preferable to a democratic one.

- For people like me, it does not matter whether a government is democratic or authoritarian.

We also study the determinants of the demand for more specific aspects of democracy, such as law and order, independence of the press or of the courts system (Q.3.12). Finally, we verify that the support to democracy comes with trust in democratic institutions, using question q3.03 (see section 5.3).

\subsection{Frontier-zones}

The LITS survey is based on Primary Sample Units ${ }^{12}$, each containing 20 observations (surveyed persons). We use the geographical map of the survey in order to identify groups of

\footnotetext{
${ }^{12}$ Primary Sampling Units were selected randomly, with probability proportional to size.
} 
PSUs which are located on both sides and in the immediate vicinity of a political frontier. We identify 37 frontier-zones that contains from 40 to 460 observations, concentrated in 2 (Slovakia-Ukraine) to 24 (Croatia-Slovenia) PSUs.

The validity of our identification assumption relies on the intensity of market integration on either side of borders. This makes little doubt for the new ten EU members, among which goods and persons are free to circulate. This is also true of many neighboring countries in most part of Central, Eastern Europe and South Eastern Europe (for example the Slovak and the Czech Republics; Albania, Macedonia and Montenegro ${ }^{13}$; Bulgaria and Macedonia or Moldova and Romania). Many countries of the sample are integrated in Euro-Regions, the purpose of which is to promote trans-frontier cooperation ${ }^{14}$. Even the relationships between countries of the former Yugoslavia have eased to a large extent in the last few years, with, for example, the relaxation of visa procedures between Serbia and Croatia in 2003. Two CIS countries: Belarus and Ukraine are also integrated in Euro-Regions ${ }^{15}$. This implies deeper cross border integration between these neighbor countries, despite the relative closeness of Ukraine and Belarus. These countries are also largely integrated with Russia, historically and formally, in the Neman Euro-Region that also includes Lithuania and Poland.

In the particular case of Central Asia and the Caucasus, patterns of trade have changed less rapidly than in Eastern Europe (Babetskii et al, 2003; Broadman, 2005). While the costs of intra-regional trade have likely increased with the creation of independent countries (Djankov and Freund, 2000) and by the recent nationalist stance of some countries, such as Uzbekistan, these countries appear to be "overtrading” among themselves ${ }^{16}$.

We leave out of our sample frontiers that are impaired by geographical obstacles or either

\footnotetext{
${ }^{13}$ As well as Kosovo, but Kosovo was excluded from our sample.

${ }^{14}$ For example, Albania, Bosnia- Herzegovina, Croatia, Montenegro and Slovenia are part of the Adriatic Euroregion; Latvia, Lithuania, Poland and Russia are part of the Baltic Euroregion (alongside with Sweden and Denmark); the Czech Republic, Poland, Slovakia constitute the Beskydy Mountains Euroregion; and trade among Hungary, Romania, and Serbia is facilitated in the Danube - Kris - Mures - Tisza Euroregion.

${ }^{15}$ Białowieża Forest Euroregion between Poland and Belarus, the BUG Euro-Region between Belarus, Poland, Ukraine, or the Carpathian Euro-Region between Hungary, Poland, Romania, Slovakia.

${ }^{16}$ Using relative prices of a bundle of goods to complement official trade data, Grafe et al. (2005) show that the impact of borders on trade between Kazakhstan, Kyrgyzstan, Uzbekistan and Tajikistan is much smaller than what the view of cumbersome crossing border procedures and licensing systems would imply. The authors attribute this result to the large development of shuttle trade in this region.
} 
restricted or closed because of political tensions and disputed territories. We thus exclude the frontiers between Georgia and Russia, Armenia and Azerbaijan, Moldova and Ukraine, as well as all Uzbek borders.

De facto, we verify that the degree of market development is more similar between two adjacent frontier-zones than it is in average between two adjacent countries. We calculate, for each frontier-zone between two countries $\mathrm{i}$ and $\mathrm{j}$ of the survey, the index of market development (defined infra in section 4.3) of frontier-zone i and frontier-zone $j$, and of country $\mathrm{i}$ and country $\mathrm{j}$ in average. Table 1 shows that on average, the correlation between indices of industrial market development is twice as high concerning adjacent frontier-zones of the sample as it is between adjacent countries of the sample. If one restricts the analysis to subsets of formerly more integrated countries, the proximity between adjacent frontier-zones appears even higher. For instance, in central Asia, the correlation between two adjacent frontier-zones is 0.78 against 0.34 in two adjacent countries (row 5 of Table 1).

Table 1. Industrial Market Development Indices at Frontier-Zones

\begin{tabular}{|c|c|c|}
\hline $\begin{array}{l}\text { Correlation between industrial market development } \\
\text { indices : }\end{array}$ & Adjacent frontiers & Adjacent countries \\
\hline Whole sample & 0.68 & 0.46 \\
\hline CIS & 0.25 & -0.02 \\
\hline Baltic countries & 0.87 & 0.49 \\
\hline European Union & 0.78 & 0.34 \\
\hline Central Asia & 0.78 & 0.11 \\
\hline Former Yougoslavia & 0.08 & -0.28 \\
\hline Former Ottoman Empire & 0.11 & -0.31 \\
\hline
\end{tabular}

Number of observations (frontier-zones): whole sample: 65; CIS (Armenia, Azerbaijan, Belarus, Georgia, Kazakhstan, Kyrgyzstan, Moldova, the Russian Federation, Ukraine and Tajikistan): 28; Baltic states: 8; EU: 28; Central Asia (Kazakhstan, Kyrgyzstan, Tajikistan): 5; Former Yugoslavia (Bosnia, Croatia, Macedonia, Montenegro, Serbia and Slovenia): 12; Former Ottoman Empire (Albania, Armenia, Bosnia, Bulgaria, Macedonia, Montenegro and Serbia): 14.

For each pair of frontier-zones between two countries $i$ and $j$, the average industrial indices of market liberalization (cf infra) are calculated at the level of frontier zone $\mathrm{i}$ and frontier zone $\mathrm{j}$ and of country $\mathrm{i}$ and country j. 


\subsection{Indices of market liberalization}

We build a regional industrial score of market liberalization, using questions about the respondents' first, second and third jobs ${ }^{17}$. The score is the regional proportion of respondents who declare that they either: work in a small enterprise, work in a medium enterprise, work in a private firm, work in a newly created enterprise (since 1989), are self-employed with more than 5 employees or have a formal labor contract.

During the socialist era, Soviet economies were distinguished by their exceptionally low proportion of Small and Medium Enterprises (SMEs). The necessities of central planning favored the organization of production and distribution in large units. We thus interpret the presence of SMEs as an indicator of market development. The presence of private firms and newly created firms are also a sign of progress in the Transition, an essential aspect of which is the process of privatization of the formerly dominant state-owned sector and the elimination of former monopolies under the pressure of new competitive firms (Berkowitz and Jackson, 2005). Self-employed persons with at least 5 employees are also part of this new economic pattern that is typical of a market economy and was absent from the landscape of planned economies. We do not count self-employed persons without employees on the grounds that those are likely not to be small firms but rather forms of quasi unofficial economy or what is sometimes called “disguised unemployment” (Earle and Sakova, 2000). Finally, we interpret the existence of a labor contract as a sign that the person is working in the official sector rather than in the informal sector, a sign of development of the market. This industrial regional score varies from 0 to 5 with an average of 2.37 .

The quality of these indices of market liberalization is limited by the lack of representativeness of the data at the regional level. However, there is no alternative regional index of private sector development or market liberalization available for the whole set of countries.

\footnotetext{
${ }^{17}$ Multiple jobs are frequent in Transition countries.
} 


\section{Results}

Although simple correlations show that supporting the market and supporting democracy are highly correlated attitudes (the correlation coefficient between the first modality of question q3.10 and question q3.11 is 0,45 ), our identification strategies leads to a different picture. We find that democracy does increase the support to market liberalization, but that the reverse relation is not as clear-cut. This pattern is apparent even in descriptive statistics. Table A2 shows that at frontier zones, the support for a market economy tends to be higher on the border of the country that enjoys a higher level of democracy (according to the Freedom House Nations in Transit ranking). Table A3 however shows that preferences for democracy within a given country do not seem to be consistently higher in the frontier zones where the market is most advanced.

\subsection{Democracy raises the support to the market}

Table 1 presents the general regressions of support to the market (equation 1'”) on, alternatively, the Freedom House Nations in Transit 2006 (Freedom House, 2006a) democracy index (Columns 1 to 3 ), and on a dummy variable representing the relative advancement of democracy, for each group of PSUs located at the frontier-zones of the survey (Columns 4 to 7). The Freedom House Nations in Transit 2006 (Freedom House, 2006a) democracy index takes values from 1 to 7, with 1 representing the highest level of democratic progress and 7 the lowest; we have recoded it in order to present the score of democracy in an ascending order. The constructed dummy variable attributes a score of 1 to the PSUs located in the most democratic country of each pair, and 0 to PSUs located in the country which fares worse in terms of the political scale, according to the Freedom House (Freedom House, 2006a and b), Polity IV (CIDCM, 2006) or other indices (see Table A4 in the Annex). For a given border we only retain the PSUs that are located at the frontier-zone (30 km around the border). All regressions are thus performed on the sub-sample of people living in frontier-zones. We control for frontier zone dummies and we adjust standard errors for clustering on frontier zones. Finally, in Table A7 (Annex), the regressions are performed 
within each border-zone.

Columns 1 and 4 in Table 2 analyze the determinants of the probability to declare that " $a$ market economy is preferable to any other form of economic system". Both the coefficients on the democratic index and the more democratic dummy variable are significant. Column 1 displays the marginal effect of a change in the Freedom House Nations in Transit democratic score, while the coefficient on the variable "more democracy" represents the effect of a discrete change of this dummy variable from 0 to 1 (on the probability to support the market). Hence, column 4 in Table 2 shows that conditionally on living in a frontier-zone, living on the "more democratic" side of the frontier increases the probability of supporting the market by about $8.4 \%$.

Columns 2 and 5 analyze the determinants of the probability to declare that "under some circumstances, a planned economy may be preferable to a market economy". Column 2 shows that an incremental change in the democracy score does not significantly affect preferences for the market. However, the coefficient on the "more democracy" dummy variable is significant at $5 \%$, as it captures more significant changes in democratic advances. Column 5 thus indicates that conditionally on living in a frontier zone, experiencing a more democratic regime reduces the probability of favoring a planned economy by roughly $6,7 \%$.

Finally, columns 3 and 6 analyze the probability of declaring that "for people like me, it does not matter whether the economic system is organized as a market economy or a planned economy". It shows that democratic variation across frontier zones has no impact on such an attitude.

Other rows of Table 2 display the other correlates of attitudes to the market. We distinguish three income categories (the richest, middle and poorest quantile inside each country), 6 educational levels, occupational categories, and employment status (self-employed versus employees). Self-employed workers tend to be more supportive of the market, while elder people and the poorest $30 \%$ of the population are less so. 
Table 2. Democracy Increases the Support to Market Development dprobit Regressions of Support to the Market

\begin{tabular}{|c|c|c|c|c|c|c|}
\hline & $\begin{array}{l}-1 \\
\text { Market is } \\
\text { preferable }\end{array}$ & $\begin{array}{l}-2 \\
\text { Plan is } \\
\text { preferable }\end{array}$ & $\begin{array}{l}-3 \\
\text { Does not } \\
\text { matter }\end{array}$ & $\begin{array}{l}-4 \\
\text { Market is } \\
\text { preferable }\end{array}$ & $\begin{array}{l}-5 \\
\text { Plan is } \\
\text { preferable }\end{array}$ & $\begin{array}{l}-6 \\
\text { Does not } \\
\text { matter }\end{array}$ \\
\hline Democracy index & $\begin{array}{l}\mathbf{0 . 0 4 0} * * * \\
{[0.015]}\end{array}$ & $\begin{array}{l}\mathbf{- 0 . 0 2 6} \\
{[0.019]}\end{array}$ & $\begin{array}{l}\mathbf{- 0 . 0 1 2} \\
{[0.017]}\end{array}$ & & & \\
\hline More democracy & & & & $\begin{array}{l}\mathbf{0 . 0 8 4} * * \\
{[0.034]}\end{array}$ & $\begin{array}{l}-\mathbf{0 . 0 6 6} * * \\
{[0.028]}\end{array}$ & $\begin{array}{l}\mathbf{- 0 . 0 1 5} \\
{[0.026]}\end{array}$ \\
\hline Adult (35-19) & $\begin{array}{l}-0.068 * * * \\
{[0.015]}\end{array}$ & $\begin{array}{l}0.052 * * * \\
{[0.016]}\end{array}$ & $\begin{array}{l}0.018 \\
{[0.018]}\end{array}$ & $\begin{array}{l}-0.069 * * * \\
{[0.015]}\end{array}$ & $\begin{array}{l}0.053^{* * *} \\
{[0.016]}\end{array}$ & $\begin{array}{l}0.016 \\
{[0.018]}\end{array}$ \\
\hline Mid-age (50-65) & $\begin{array}{l}-0.094 * * * \\
{[0.021]}\end{array}$ & $\begin{array}{l}0.056^{* * *} \\
{[0.020]}\end{array}$ & $\begin{array}{l}0.042 * \\
{[0.024]}\end{array}$ & $\begin{array}{l}-0.094 * * * \\
{[0.020]}\end{array}$ & $\begin{array}{l}0.056 * * * \\
{[0.020]}\end{array}$ & $\begin{array}{l}0.041^{*} \\
{[0.023]}\end{array}$ \\
\hline Old $(>65)$ & $\begin{array}{l}-0.153 * * * \\
{[0.024]}\end{array}$ & $\begin{array}{l}0.060 * * \\
{[0.030]}\end{array}$ & $\begin{array}{l}0.089 * * * \\
{[0.025]}\end{array}$ & $\begin{array}{l}-0.158 * * * \\
{[0.024]}\end{array}$ & $\begin{array}{l}0.063 * * \\
{[0.030]}\end{array}$ & $\begin{array}{l}0.089 * * * \\
{[0.024]}\end{array}$ \\
\hline Poor & $\begin{array}{l}-0.066^{* * *} \\
{[0.018]}\end{array}$ & $\begin{array}{l}-0.01 \\
{[0.016]}\end{array}$ & $\begin{array}{l}0.071 * * * \\
{[0.016]}\end{array}$ & $\begin{array}{l}-0.063^{* * *} \\
{[0.018]}\end{array}$ & $\begin{array}{l}-0.011 \\
{[0.015]}\end{array}$ & $\begin{array}{l}0.071 * * * \\
{[0.016]}\end{array}$ \\
\hline Rich & $\begin{array}{l}0.015 \\
{[0.021]}\end{array}$ & $\begin{array}{l}-0.004 \\
{[0.015]}\end{array}$ & $\begin{array}{l}-0.012 \\
{[0.014]}\end{array}$ & $\begin{array}{l}0.011 \\
{[0.020]}\end{array}$ & $\begin{array}{l}-0.001 \\
{[0.014]}\end{array}$ & $\begin{array}{l}-0.01 \\
{[0.013]}\end{array}$ \\
\hline Male & $\begin{array}{l}-0.018 \\
{[0.032]}\end{array}$ & $\begin{array}{l}0.096 * * * \\
{[0.033]}\end{array}$ & $\begin{array}{l}-0.053 \\
{[0.032]}\end{array}$ & $\begin{array}{l}-0.014 \\
{[0.031]}\end{array}$ & $\begin{array}{l}0.100^{* * *} \\
{[0.031]}\end{array}$ & $\begin{array}{l}-0.060 * * \\
{[0.030]}\end{array}$ \\
\hline Compulsory education & $\begin{array}{l}0.04 \\
{[0.035]}\end{array}$ & $\begin{array}{l}0.132^{* * * *} \\
{[0.034]}\end{array}$ & $\begin{array}{l}-0.129 * * * \\
{[0.035]}\end{array}$ & $\begin{array}{l}0.047 \\
{[0.034]}\end{array}$ & $\begin{array}{l}0.131^{* * *} \\
{[0.032]}\end{array}$ & $\begin{array}{l}-0.135^{* * *} \\
{[0.033]}\end{array}$ \\
\hline Secondary education & $\begin{array}{l}0.056 * \\
{[0.032]}\end{array}$ & $\begin{array}{l}0.126^{* * *} \\
{[0.028]}\end{array}$ & $\begin{array}{l}-0.141 * * * \\
{[0.030]}\end{array}$ & $\begin{array}{l}0.062 * * \\
{[0.031]}\end{array}$ & $\begin{array}{l}0.125^{* * *} \\
{[0.028]}\end{array}$ & $\begin{array}{l}-0.144 * * * \\
{[0.027]}\end{array}$ \\
\hline Professional education & $\begin{array}{l}0.109 * * * \\
{[0.034]}\end{array}$ & $\begin{array}{l}0.191^{* * * *} \\
{[0.034]}\end{array}$ & $\begin{array}{l}-0.229 * * * \\
{[0.026]}\end{array}$ & $\begin{array}{l}0.115^{* * *} \\
{[0.033]}\end{array}$ & $\begin{array}{l}0.188^{* * *} \\
{[0.033]}\end{array}$ & $\begin{array}{l}-0.231 * * * \\
{[0.024]}\end{array}$ \\
\hline University education & $\begin{array}{l}0.027 \\
{[0.076]}\end{array}$ & $\begin{array}{l}0.199 * * * \\
{[0.076]}\end{array}$ & $\begin{array}{l}-0.147^{* * *} \\
{[0.045]}\end{array}$ & $\begin{array}{l}0.042 \\
{[0.078]}\end{array}$ & $\begin{array}{l}0.190 * * \\
{[0.077]}\end{array}$ & $\begin{array}{l}-0.151 * * * \\
{[0.042]}\end{array}$ \\
\hline Postgraduate education & $\begin{array}{l}0.051^{* * *} \\
{[0.010]}\end{array}$ & $\begin{array}{l}-0.002 \\
{[0.011]}\end{array}$ & $\begin{array}{l}-0.048 * * * \\
{[0.011]}\end{array}$ & $\begin{array}{l}0.053 * * * \\
{[0.010]}\end{array}$ & $\begin{array}{l}-0.003 \\
{[0.011]}\end{array}$ & $\begin{array}{l}-0.049 * * * \\
{[0.011]}\end{array}$ \\
\hline Unemployed & $\begin{array}{l}0.003 \\
{[0.027]}\end{array}$ & $\begin{array}{l}-0.01 \\
{[0.028]}\end{array}$ & $\begin{array}{l}0.008 \\
{[0.025]}\end{array}$ & $\begin{array}{l}0.008 \\
{[0.027]}\end{array}$ & $\begin{array}{l}-0.014 \\
{[0.027]}\end{array}$ & $\begin{array}{l}0.009 \\
{[0.024]}\end{array}$ \\
\hline Self employed & $\begin{array}{l}0.101^{* * *} \\
{[0.027]}\end{array}$ & $\begin{array}{l}-0.089 * * * \\
{[0.018]}\end{array}$ & $\begin{array}{l}-0.009 \\
{[0.025]}\end{array}$ & $\begin{array}{l}0.116^{* * *} \\
{[0.027]}\end{array}$ & $\begin{array}{l}-0.098 * * * \\
{[0.018]}\end{array}$ & $\begin{array}{l}-0.013 \\
{[0.023]}\end{array}$ \\
\hline White collar worker & $\begin{array}{l}0.052 \\
{[0.036]}\end{array}$ & $\begin{array}{l}0.005 \\
{[0.027]}\end{array}$ & $\begin{array}{l}-0.069 * * \\
{[0.032]}\end{array}$ & $\begin{array}{l}0.058 \\
{[0.036]}\end{array}$ & $\begin{array}{l}-0.004 \\
{[0.027]}\end{array}$ & $\begin{array}{l}-0.063^{* *} \\
{[0.031]}\end{array}$ \\
\hline Blue collar worker & $\begin{array}{l}0.003 \\
{[0.033]}\end{array}$ & $\begin{array}{l}0.027 \\
{[0.028]}\end{array}$ & $\begin{array}{l}-0.029 \\
{[0.029]}\end{array}$ & $\begin{array}{l}0.001 \\
{[0.032]}\end{array}$ & $\begin{array}{l}0.024 \\
{[0.027]}\end{array}$ & $\begin{array}{l}-0.021 \\
{[0.028]}\end{array}$ \\
\hline Service worker & $\begin{array}{l}0.035 \\
{[0.033]}\end{array}$ & $\begin{array}{l}-0.009 \\
{[0.025]}\end{array}$ & $\begin{array}{l}-0.028 \\
{[0.033]}\end{array}$ & $\begin{array}{l}0.045 \\
{[0.033]}\end{array}$ & $\begin{array}{l}-0.017 \\
{[0.024]}\end{array}$ & $\begin{array}{l}-0.026 \\
{[0.032]}\end{array}$ \\
\hline Farmer, farm worker & $\begin{array}{l}0.04 \\
{[0.051]}\end{array}$ & $\begin{array}{l}0.012 \\
{[0.032]}\end{array}$ & $\begin{array}{l}-0.044 \\
{[0.047]}\end{array}$ & $\begin{array}{l}0.059 \\
{[0.050]}\end{array}$ & $\begin{array}{l}-0.003 \\
{[0.031]}\end{array}$ & $\begin{array}{l}-0.05 \\
{[0.045]}\end{array}$ \\
\hline Pensioner & $\begin{array}{l}-0.012 \\
{[0.036]}\end{array}$ & $\begin{array}{l}0.005 \\
{[0.021]}\end{array}$ & $\begin{array}{l}0.001 \\
{[0.028]}\end{array}$ & $\begin{array}{l}-0.002 \\
{[0.036]}\end{array}$ & $\begin{array}{l}-0.003 \\
{[0.022]}\end{array}$ & $\begin{array}{l}0.003 \\
{[0.028]}\end{array}$ \\
\hline Student & $\begin{array}{l}0.025 \\
{[0.059]}\end{array}$ & $\begin{array}{l}0.008 \\
{[0.045]}\end{array}$ & $\begin{array}{l}-0.033 \\
{[0.043]}\end{array}$ & $\begin{array}{l}0.031 \\
{[0.057]}\end{array}$ & $\begin{array}{l}0.001 \\
{[0.043]}\end{array}$ & $\begin{array}{l}-0.029 \\
{[0.042]}\end{array}$ \\
\hline Housewife & $\begin{array}{l}0.05 \\
{[0.048]}\end{array}$ & $\begin{array}{l}-0.024 \\
{[0.028]}\end{array}$ & $\begin{array}{l}-0.024 \\
{[0.043]}\end{array}$ & $\begin{array}{l}0.062 \\
{[0.048]}\end{array}$ & $\begin{array}{l}-0.036 \\
{[0.028]}\end{array}$ & $\begin{array}{l}-0.024 \\
{[0.042]}\end{array}$ \\
\hline Observations & 6750 & 6750 & 6750 & 6970 & 6970 & 6970 \\
\hline log likelihood & -4254.41 & -3691.65 & -3982.12 & -4391.74 & -3796.55 & -4041.41 \\
\hline Pseudo R2 & 0.0696 & 0.0328 & 0.0754 & 0.0746 & 0.0331 & 0.0829 \\
\hline
\end{tabular}


Controls: frontier zone dummies.

Omitted categories: young (17-34) average income, lowest education, employee, occupation in army.

Robust standard errors adjusted for clustering on frontier zones.

If one accepts the assumption that people living in a common frontier-zone share the same practical experience of market development (and the same background culture), the lesson of Table 2 is that living in a country with a higher degree of democracy exerts a positive influence on the declared support to the market.

As a robustness check, we have run the same regression as column 4 of Table 2 within each frontier-zone. The positive effect of democratic institutions on the support for the market proves particularly strong and significant at borders that are well integrated both culturally and economically (see Table A6 in the Annex for the quality of market integration at frontierzones). This is notably the case for the Moldova-Romania frontier or the Estonia-Latvia frontier. The effect is also strong for the Belarus-Lithuania, Belarus-Poland and UkraineRussia frontier-zones, all formerly part of the Polish Empire and currently highly integrated.

The effect is globally well respected except for most Hungarian frontiers and the BulgariaRomania, Croatia-Serbia and Poland-Ukraine frontier-zones. The unexpected results for Hungary are certainly explained by the difficult situation of the country, which, at the time of the LITS survey, was going through a sharp confidence crisis after the diffusion by the media of a broadcast of the Prime Minister trying to bribe a deputy. Concerning the BulgariaRomania frontier, the fact that the development of democracy in the two countries is very close, as shown by the identical ranking of these countries by other democracy indices, like Polity IV (CIDCM, 2006) might explain why the sign of the coefficient of "More Democratic" is reversed. The same reason may explain why many coefficients are insignificant at the borders of countries that experience similar level of democracy, such as the Czech Republic and Poland (which obtain the same ratings by both Freedom in the World (Freedom House, 2006b) and Polity IV (CIDCM, 2006)), Bulgaria and Macedonia or Bosnia and Croatia. Other results are impaired by the fact that economic integration may be only partial at some borders, such as the frontier between Croatia and Serbia, where heavy restrictions were lifted only in 2003.

We verified that our results do not hold when the frontiers that were excluded from our 
sample for being closed or severely restricted are considered. For instance, the coefficient inside the Armenia-Azerbaijan border zone is -0.070 (0.128); it is of $-0.3283(0.207)$ in the Kazak-Uzbek frontier-zone; of -0.097* (0.051) in the Kyrgyz-Uzbek and of 0.004 (0.696) in the Moldova-Ukraine zone. Considering all the closed border-zones together (and controlling for border-zones dummies), the coefficient on the freedom house democracy index is 0.039 (0.053) in the regression of the support to the market. Hence the relation is not significant in closed frontier-zones, which is consistent with our interpretation of regional integration.

In order to go one step further in the attempt to control for "cultural" omitted factors, we now estimate equation (1'’) within various sub-samples of frontier-zones belonging to historically integrated regions. Table 3 presents the regressions by “cultural zones” as defined in section 3.2. Market development still exerts a positive and significant effect on the demand for democracy among countries of the former Ottoman Empire, countries of the former Yugoslavia, countries of the former Polish Empire and countries of the CIS, as well as among the subset of Central Asia.

The effect is particularly strong in countries that have experienced a strong degree of integration in the past ${ }^{18}$, such as the USSR, and a fortiori the CIS and Central Asia, where, in addition, today's frontiers are often arbitrary. The effect is also significant in the former Yugoslavia and the Polish Empire. By contrast, it is not significant for the countries of the former Austro-Hungarian Empire. A possible interpretation is that the relation between democratic institutions and the support for the market is particularly strong for less developed countries. Another possible interpretation is that the countries of the former AustroHungarian Empire are too close in terms of democratic development for the effect to be sizeable.

\footnotetext{
${ }^{18}$ As these countries have shared a common experience of a planned economy; it would be farfetched to suspect some reverse causality running from people's current attitudes towards the market to the current degree of democracy.
} 
Table 3. Democracy and Support to the Market within Cultural Areas

dprobit Estimates of Support to the Market

\begin{tabular}{|c|c|c|c|c|c|c|c|}
\hline & $\begin{array}{l}-1 \\
\text { Austro } \\
\text { Hungarian }\end{array}$ & $\begin{array}{l}-2 \\
\text { Ottoman }\end{array}$ & $\begin{array}{l}-3 \\
\text { Yugoslavia }\end{array}$ & $\begin{array}{l}-6 \\
\text { Polish } \\
\text { Empire }\end{array}$ & $\begin{array}{l}-4 \\
\text { CIS }\end{array}$ & $\begin{array}{l}-5 \\
\text { Central } \\
\text { Asia }\end{array}$ & $\begin{array}{l}-7 \\
\text { USSR }\end{array}$ \\
\hline Democracy index & $\begin{array}{l}\mathbf{0 . 0 3 1} \\
{[0.021]}\end{array}$ & $\begin{array}{l}\mathbf{0 . 1 3 7} \\
{[0.129]}\end{array}$ & $\begin{array}{l}\mathbf{0 . 0 6 8} * * \\
{[0.026]}\end{array}$ & $\begin{array}{l}\mathbf{0 . 0 2 9 5} * * \\
{[0.012]}\end{array}$ & $\begin{array}{l}\mathbf{0 . 0 4 6} * * * \\
{[0.013]}\end{array}$ & $\begin{array}{l}\mathbf{0 . 2 3 1} * * * \\
{[0.043]}\end{array}$ & $\begin{array}{l}\mathbf{0 . 0 3 4} * * * \\
{[0.010]}\end{array}$ \\
\hline Observations & 1656 & 1920 & 2134 & 1734 & 2354 & 740 & 2994 \\
\hline Log likelihood & -1022 & -1277 & -1373 & -1064 & -1458 & -443 & -2008 \\
\hline Pseudo R2 & 0.072 & 0.032 & 0.041 & 0.094 & 0.081 & 0.117 & 0.073 \\
\hline
\end{tabular}

Controls: income categories, age categories, gender, occupation categories, self employed, education.

Robust standard errors adjusted for clustering on frontier zones.

The Austro Hungarian zone comprises Croatia, Czech Republic, Hungary, Slovak Republic and Slovenia. The Ottoman zone comprises Albania, Armenia, Bosnia, Bulgaria, Macedonia, Montenegro and Serbia. Yugoslavian zone comprises Bosnia, Croatia, Macedonia, Montenegro, Serbia and Slovenia. The Commonwealth of Independent states (CIS) consists of Armenia, Azerbaijan, Belarus, Georgia, Kazakhstan, Kyrgyzstan, Moldova, the Russian Federation, Tajikistan, Ukraine and Uzbekistan. The former USSR comprises all of the CIS, plus Estonia, Latvia and Lithuania. Central Asia consists of Kazakhstan, Kyrgyzstan, Tajikistan and Uzbekistan. The Polish Empire zone comprises Belarus, Lithuania, Poland, Ukraine, the Russian Federation (western borders). EU zone comprises Bulgaria, the Czech Republic, Estonia, Latvia, Lithuania, Hungary, Poland, Romania, the Slovak Republic and Slovenia.

As a robustness check, we also test different indicators of democracy and different country rankings (see the Annex). The result that the development of democracy positively and significantly influences the demand for the market is preserved using the Freedom of the World (Freedom House, 2006b) or BTI indicators (Bertelsmann Stiftung, 2005).

\subsection{Market liberalization does not raise the support for democracy}

We now address the symmetric question whether market liberalization comforts the support for democracy. We need to make sure that the attitude toward democracy that is observed is not caused by the degree of democratization already reached in the country of the respondent. Hence, we need to find some groups of citizens who experience a common political environment with different degrees of market liberalization. As explained in section 2, we rely on the evidence that there are wide regional differences within the countries of the former Soviet block and Eastern and Southern Europe (e.g. EBRD, 2006). We build an index 
of market advance at the regional level, which is based on the regional market structure (size and type of firms).

Table 4 shows the regressions of the support to democracy on indices of regional market development. Because the impact of market development on attitudes towards democracy could be driven by metropolitan regions in which market liberalization is well in advance of other regions, and where people are also likely to have different political attitudes, we include a control for the type of area (metropolitan/urban/rural) in all regressions. We checked that the results are essentially unchanged when these controls are not performed and when metropolitan regions are dropped from the sample.

Columns 1 to 3 present the regression of individual preferences for the political regime on our index of market development across all regions of a given country. Columns 4 to 6 present an alternative specification where we restrict the sample to open frontiers, and measure the effect of market development in the various frontier zones of a country. Lastly, columns 7 to 9 display the result of a third specification where the degree of market development of a frontier-zone $\mathrm{j}$ is proxied by the degree of market development of the adjacent region $\mathrm{k}$ across the frontier (cf section 3.2). As explained in section 3.2, the two latter specifications are useful in order to avoid the risk that the observed relationship between market development and support to democracy is due to reverse causality.

Columns 1, 4 and 7 analyze the determinants of the probability to declare that "democracy is preferable to any other form of political system". Surprisingly, the index of market development has no impact on this variable, in any of the specifications. Identically, the probability of choosing the modality "for people like me, it does not matter whether a government is democratic or authoritarian” (columns 3, 6 and 9) does not depend on the index of market development.

Columns 2, 5 and 8 analyze the determinants of the probability to declare that "under some circumstances, an authoritarian government may be preferable to a democratic one”. Here, market development has a negative and significant effect when the sample is restricted to frontier zones of a given country. Hence, conditionally on living in a frontier zone, living close to a country where the market is more advanced and benefiting from this market development thanks to cross border market integration reduces individual support for authoritarian regime. However, this effect is not significant when all regions of the country 
are considered (columns 2.5 and 8).

Market liberalization thus does not appear to reinforce democratic values. Other effects indicate that the richer, better educated, younger, self-employed people and surprisingly, farmers and farm-workers, are more supportive of democracy. On the contrary, the poor, those who have not completed compulsory education and women are less supportive of democracy and more likely to declare that the political system does not matter for them. 
Table 4. Support to Democracy and Regional Indices of Market Liberalization

dprobit Estimates of Support to Democracy/Authoritarianism

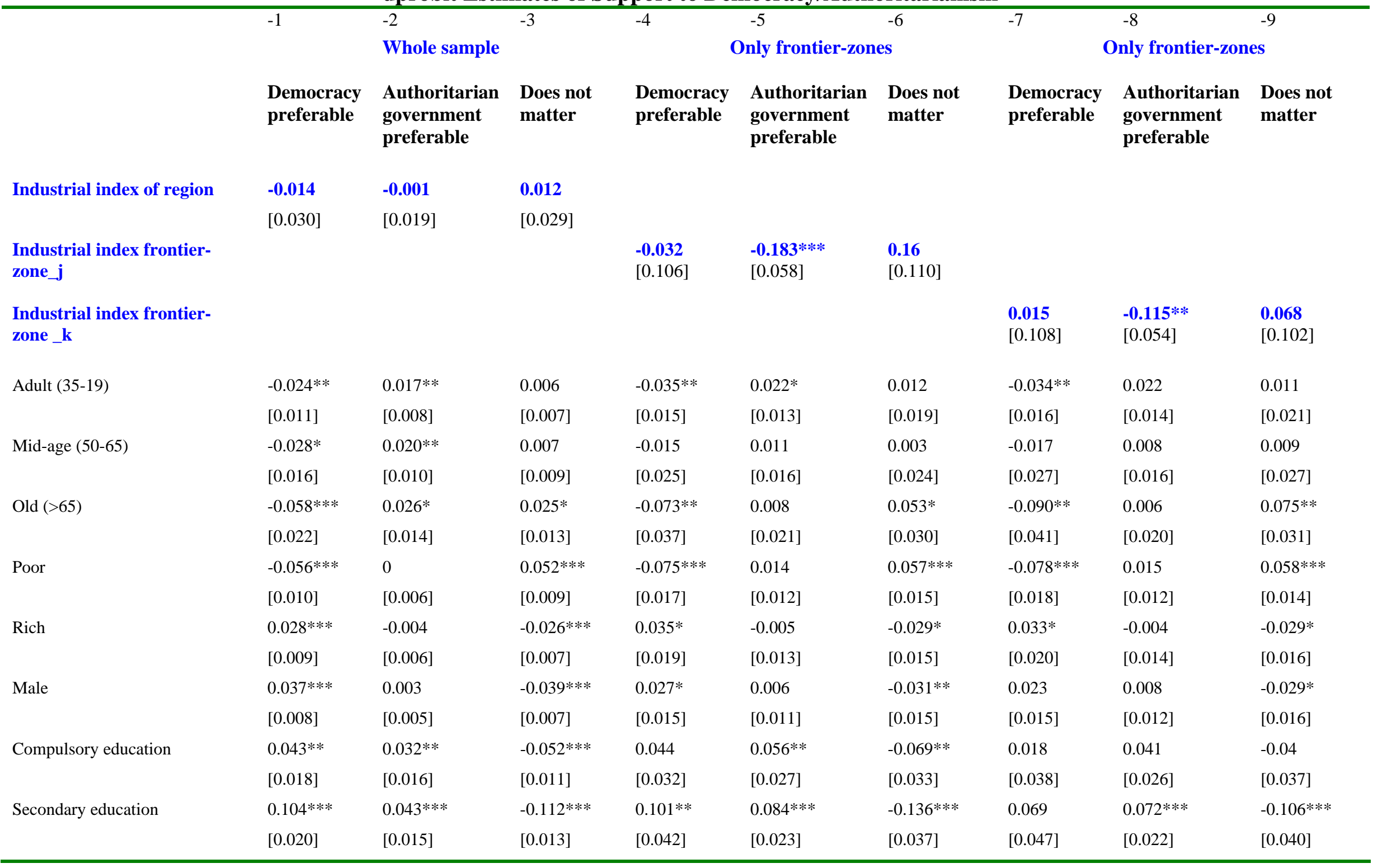




\begin{tabular}{|c|c|c|c|c|c|c|c|c|c|}
\hline Professional education & $\begin{array}{l}0.117 * * * \\
{[0.017]}\end{array}$ & $\begin{array}{l}0.049 * * * \\
{[0.015]}\end{array}$ & $\begin{array}{l}-0.129 * * * \\
{[0.014]}\end{array}$ & $\begin{array}{l}0.125 * * * \\
{[0.036]}\end{array}$ & $\begin{array}{l}0.085 * * * \\
{[0.024]}\end{array}$ & $\begin{array}{l}-0.161 * * * \\
{[0.034]}\end{array}$ & $\begin{array}{l}0.094 * * \\
{[0.041]}\end{array}$ & $\begin{array}{l}0.074 * * * \\
{[0.023]}\end{array}$ & $\begin{array}{l}-0.130 * * * \\
{[0.034]}\end{array}$ \\
\hline \multirow[t]{2}{*}{ University education } & $0.186^{* * *}$ & $0.056^{* * *}$ & $-0.191 * * *$ & $0.193 * * *$ & $0.109 * * *$ & $-0.222 * * *$ & $0.161^{* * *}$ & $0.109 * * *$ & $-0.207 * * *$ \\
\hline & {$[0.018]$} & {$[0.014]$} & {$[0.011]$} & {$[0.040]$} & {$[0.030]$} & {$[0.025]$} & {$[0.044]$} & {$[0.027]$} & {$[0.028]$} \\
\hline \multirow[t]{2}{*}{ Post graduate education } & $0.252 * * *$ & 0.015 & $-0.204 * * *$ & $0.169 * * *$ & $0.142 * *$ & $-0.200 * * *$ & $0.140^{* *}$ & $0.151^{* *}$ & $-0.200 * * *$ \\
\hline & {$[0.025]$} & {$[0.025]$} & {$[0.012]$} & {$[0.060]$} & {$[0.066]$} & {$[0.032]$} & {$[0.062]$} & {$[0.062]$} & [0.039] \\
\hline \multirow[t]{2}{*}{ Unemployed } & 0.021 & -0.015 & -0.004 & 0.033 & $-0.034 *$ & 0.008 & 0.008 & -0.016 & 0.011 \\
\hline & {$[0.018]$} & {$[0.013]$} & {$[0.015]$} & {$[0.032]$} & [0.019] & {$[0.023]$} & {$[0.029]$} & {$[0.019]$} & [0.021] \\
\hline \multirow[t]{2}{*}{ Self employed } & 0.023 & -0.014 & -0.009 & 0.03 & -0.025 & -0.005 & 0.002 & -0.02 & 0.016 \\
\hline & {$[0.022]$} & {$[0.014]$} & {$[0.015]$} & {$[0.027]$} & {$[0.022]$} & {$[0.025]$} & {$[0.025]$} & {$[0.022]$} & [0.025] \\
\hline \multirow[t]{2}{*}{ White collar worker } & $0.089 * * *$ & -0.014 & $-0.079 * * *$ & $0.081 * * *$ & -0.008 & $-0.073 * * *$ & $0.066^{* *}$ & 0.006 & $-0.074 * * *$ \\
\hline & {$[0.013]$} & {$[0.010]$} & {$[0.012]$} & {$[0.026]$} & {$[0.020]$} & {$[0.024]$} & {$[0.026]$} & {$[0.022]$} & {$[0.026]$} \\
\hline \multirow[t]{2}{*}{ Blue collar worker } & $0.029 *$ & -0.012 & -0.014 & 0.035 & -0.008 & -0.022 & 0.024 & -0.002 & -0.018 \\
\hline & {$[0.016]$} & {$[0.012]$} & {$[0.015]$} & [0.029] & {$[0.022]$} & {$[0.031]$} & {$[0.032]$} & {$[0.021]$} & [0.035] \\
\hline \multirow[t]{2}{*}{ Service worker } & $0.053 * * *$ & -0.008 & $-0.043 * * *$ & $0.086 * * *$ & $-0.042 * *$ & -0.038 & $0.069 * * *$ & $-0.031^{*}$ & -0.034 \\
\hline & {$[0.014]$} & {$[0.010]$} & {$[0.013]$} & {$[0.028]$} & {$[0.019]$} & {$[0.026]$} & {$[0.026]$} & {$[0.017]$} & {$[0.028]$} \\
\hline \multirow[t]{2}{*}{ Farmer, farm worker } & $0.060 * * *$ & -0.004 & $-0.051 * * *$ & $0.069 * * *$ & 0.016 & $-0.082 * * *$ & $0.068 * *$ & 0.029 & $-0.089 * * *$ \\
\hline & {$[0.017]$} & {$[0.013]$} & {$[0.017]$} & {$[0.026]$} & {$[0.024]$} & {$[0.023]$} & {$[0.033]$} & {$[0.028]$} & {$[0.028]$} \\
\hline \multirow[t]{2}{*}{ Pensioner } & -0.002 & -0.007 & 0.007 & 0.008 & 0.009 & -0.014 & -0.004 & 0.023 & -0.015 \\
\hline & {$[0.018]$} & {$[0.010]$} & {$[0.019]$} & {$[0.034]$} & {$[0.017]$} & {$[0.030]$} & {$[0.037]$} & {$[0.016]$} & [0.033] \\
\hline \multirow[t]{2}{*}{ Student } & $0.128 * * *$ & $-0.038 * * *$ & $-0.085^{* * *}$ & 0.088 & -0.054 & -0.023 & 0.071 & -0.039 & -0.024 \\
\hline & {$[0.028]$} & {$[0.013]$} & {$[0.021]$} & {$[0.065]$} & [0.039] & {$[0.038]$} & [0.067] & {$[0.042]$} & {$[0.042]$} \\
\hline \multirow[t]{2}{*}{ Housewife } & $0.039 * *$ & $-0.034 * *$ & -0.005 & 0.022 & -0.031 & 0.013 & -0.004 & -0.014 & 0.02 \\
\hline & {$[0.018]$} & {$[0.013]$} & [0.019] & {$[0.035]$} & {$[0.025]$} & {$[0.030]$} & [0.035] & {$[0.026]$} & [0.032] \\
\hline Observations & 28909 & 28909 & 28955 & 7032 & 7032 & 7041 & 6274 & 6274 & 6281 \\
\hline log likelihood & -18624.11 & -12203.71 & -15662.88 & -4511.66 & -3055.29 & -3848.54 & -4051.73 & -2682.95 & -3491.07 \\
\hline Pseudo R2 & 0.0557 & 0.0297 & 0.0711 & 0.0685 & 0.0496 & 0.0814 & 0.0625 & 0.0456 & 0.0746 \\
\hline
\end{tabular}

Controls: urban/rural or metropole area for columns 1 to 3. Omitted categories: young (17 to 34 years old), average income group, occupation in army, employees, lowest education. Robust standard errors adjusted for clustering at the country level.

The industrial index is constructed at the regional level. Industrial index $\mathrm{j}$ is the index of market development of the zone where the respondent lives. Industrial index $\mathrm{k}$ measures the market development of the adjacent frontier-zone 
As the estimates of Table 4 are based on regional variations, it may seem confusing to pool the data of the various countries of the sample together. Hence, we run the same estimation of the support to democracy within each country of the survey. Country-wise regressions corroborate the finding that the support to democracy does not increase with the industrial development indicator. Finally, we estimate the support to democracy within each zone of deeper regional and cultural integration (Tables 5.a and 5.b). Table 5.a displays the regressions on the entire sample; the industrial index measures the score of market development at the regional level. Table 5.b shows the regression on the sub-sample of frontier-zones. The industrial index measures the sore of market development of the adjacent frontier-zone.

Essentially, regional market development again appears to exert no impact on the support to democracy. The industrial index of market development is only significant for the regions of the former Austro-Hungarian Empire; by contrast, the impact of the index is significantly negative in regions of Central Asia. Hence, the link between market development and preferences for democracy only appears in countries that are more affluent and face a higher degree of actual democracy.

Lindblom (1995) provides a possible interpretation of these findings. He defines markets and democracy as two distinct methods of popular controls over the elites. The former aims at outcomes (resources allocation) but gives no control over the processes that generate outcomes; symmetrically, the latter provides popular control over processes. In this framework, an interpretation of our findings is that the need to control processes becomes more pressing in situations where people have already secured the control over outcomes. It may also be the case that the relation is non linear, i.e. for people to care about processes, they need to have already reached a certain degree of empowerment. This would explain why the demand for democracy is stronger in societies that are already more advanced in terms of both market liberalization and democratization. 
Table 5.a. Support to Democracy and Regional Indices of Market Liberalization dprobit Estimates of Support to Democracy

Full sample

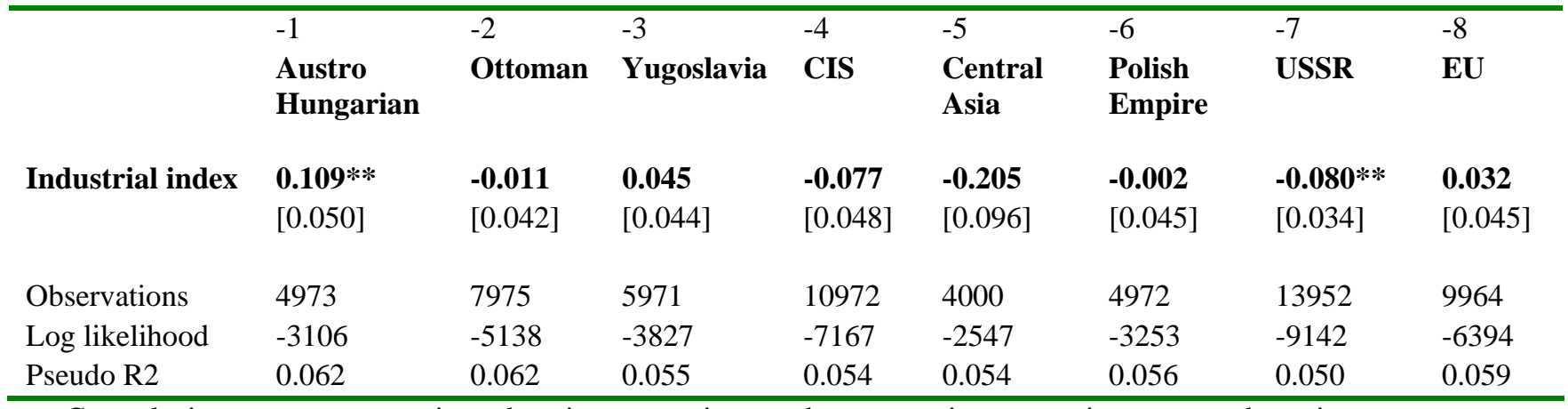

Controls: income, age categories, education categories, gender, occupation categories, country dummies.

Regions (in columns) are defined as in Table 3. Robust standard errors adjusted for clustering at country level.

The industrial index is constructed at the regional level.

Table 5b. Support to Democracy and Regional Indices of Market Liberalization dprobit Estimates of Support to Democracy

Sub-sample of Frontier-Zones

\begin{tabular}{|c|c|c|c|c|c|c|c|c|}
\hline & $\begin{array}{l}-1 \\
\text { Austro } \\
\text { Hungarian }\end{array}$ & $\begin{array}{l}-2 \\
\text { Ottoman }\end{array}$ & $\begin{array}{l}-3 \\
\text { Yugoslavia }\end{array}$ & $\begin{array}{l}-4 \\
\text { CIS }\end{array}$ & $\begin{array}{l}-5 \\
\text { Central } \\
\text { Asia }\end{array}$ & $\begin{array}{l}-6 \\
\text { Polish } \\
\text { Empire }\end{array}$ & $\begin{array}{l}-7 \\
\text { USSR }\end{array}$ & $\begin{array}{l}-8 \\
\mathbf{E U}\end{array}$ \\
\hline $\begin{array}{l}\text { Industrial index } \\
\text { frontier-zone_k }\end{array}$ & $\begin{array}{l}\mathbf{0 . 1 2 3} \\
{[0.075]}\end{array}$ & $\begin{array}{l}\mathbf{- 0 . 0 3 6} \\
{[0.085]}\end{array}$ & $\begin{array}{l}\mathbf{0 . 1 2 5} \\
{[0.082]}\end{array}$ & $\begin{array}{l}\mathbf{0 . 0 1 9} \\
{[0.133]}\end{array}$ & $\begin{array}{l}\mathbf{- 0 . 1 2 3} \\
{[0.252]}\end{array}$ & $\begin{array}{l}\mathbf{- 0 . 0 1 8} \\
{[0.087]}\end{array}$ & $\begin{array}{l}\mathbf{- 0 . 0 3 5} \\
{[0.092]}\end{array}$ & $\begin{array}{l}\mathbf{- 0 . 0 0 9} \\
{[0.073]}\end{array}$ \\
\hline Observations & 1656 & 1940 & 2134 & 3794 & 1859 & 1794 & 4414 & 2322 \\
\hline Log likelihood & -1051 & -1250 & -1365 & -2452 & -1188 & -1161 & -2869 & -1472 \\
\hline Pseudo R2 & 0.066 & 0.094 & 0.072 & 0.064 & 0.057 & 0.067 & 0.058 & 0.064 \\
\hline
\end{tabular}

Controls: income, age categories, education categories, gender, occupation categories, country dummies.

The industrial index measures the level of market development of the adjacent frontier-zone $\mathrm{k}$, when the respondent lives in frontier-zone $\mathrm{j}$.

Finally, as a robustness check, we use alternative indicators of both the explained variable (support to democracy) and the explanatory variable (market development). First, we build an index of adhesion to democratic principles based on questions of the LIT Survey. This index is based on the following question: 
Q3.12. To what extent do you agree that the following are important for your country:

Scale: Strongly disagree, Disagree, Neither agree nor disagree, Agree, Strongly Agree, Difficult to say

- Free and fair elections.

- Law and order.

- Freedom of speech.

- Peace and stability

- A press that is independent from the government.

- A strong political opposition

- A courts system that defends individual rights against abuse by the state.

- A courts system that treats all citizens equally, rather than favoring some over others.

- Protection of minority rights (religious, ethnics, etc...)

- Freedom to travel abroad

The "value of democracy" index sums the number of times a person declares to "agree" or "strongly agree" that the items listed in the above table are important. The index varies from 0 to 9 , with an average of 4,5 .

Table 6 shows the ordered probit regression of the "value of democracy" index. Column one displays the regression on the entire sample; the industrial index measures the score of market development at the regional level. Column 2 shows the regression on the sub-sample of frontier-zones. The industrial index measures the sore of market development of the adjacent frontier-zone. 
Table 6. The Value of Democracy and Regional Indices of Market Development Ordered Probit Regressions of the Score of Declared Importance of Democracy

\begin{tabular}{lcc}
\hline & $\begin{array}{c}-1 \\
\text { Entire sample } \\
\text { (industrial index of zone j) }\end{array}$ & $\begin{array}{c}-2 \\
\text { Only frontier-zones }\end{array}$ \\
Industrial index & $\mathbf{0 . 0 3 8}$ & $-\mathbf{0 . 3}$ \\
Observations & {$[0.090]$} & {$[0.232]$} \\
Log likelihood & 27955 & 6281 \\
Pseudo R2 & -61759 & -13689 \\
\hline
\end{tabular}

Controls: type of area (rural, urban or metropolitan), income, age categories, education categories, gender, occupation categories, country dummies. Robust standard errors adjusted for clustering at the country level Column 1: whole sample. Industrial index of the region j of the respondent.

Column 2: only frontier-zones. Industrial index of the adjacent frontier zone $\mathrm{k}$ when respondent live in region j.

Again regional market indices do not seem to influence the importance that citizens attach to democracy. The impact even seems to be significantly negative in regions of the CIS and of the former Polish Empire.

Of course, the indices of market development that we use may be misconstrued and it is possible that better measures of market liberalization would be found to influence the support to democracy. We regret that indices of industrial concentration are not available at the regional level for the whole set of countries in the sample ${ }^{19}$. As an alternative to the index of industrial development, we use an indicator of relative wealth. We calculate the average aggregate regional income based on the real expenditures declared by the households of the survey, relative to the national average ${ }^{20}$. This is based on the idea that aggregate income is an outcome of market development. Again, as shown by Table 7, this indicator does not exert

\footnotetext{
${ }^{19}$ In our view, indices of this type would be best suited, if they were available, than some often used indicators based on governance, the protection of legal rights, the protection of minority shareholders or indices of price liberalization. The latter have two important drawbacks: first they are only available at the national level and second, they often reflect the progress of the rule of law, i.e. of democracy itself, rather than that of the freedom of transactions on the market.

${ }^{20}$ Household expenditures were adjusted for household size using the modified OECD equivalence scale.
} 
any significant impact on the attitudes to democracy or authoritarian regimes ${ }^{21}$.

Table7. Support to democracy and relative regional income dprobit Estimates of Support to Democracy

\begin{tabular}{llll}
\hline & $\begin{array}{l}-1 \\
\text { Democracy } \\
\text { preferable }\end{array}$ & $\begin{array}{l}-2 \\
\text { Authoritarian } \\
\text { government } \\
\text { preferable }\end{array}$ & Does not matter \\
Regional level of expenditure & $\mathbf{0 . 0 2 1}$ & $\mathbf{- 0 . 0 0 2}$ & $\mathbf{- 0 . 0 1 8}$ \\
& {$[0.043]$} & {$[0.031]$} & {$[0.028]$} \\
Observations & 27960 & 27960 & 27995 \\
Log likelihood & -18089 & -11981 & -15212 \\
Pseudo R2 & 0.055 & 0.027 & 0.073 \\
\hline
\end{tabular}

Controls: income, age categories, education categories, gender, occupation categories, country dummies. The industrial index is constructed as the average regional real level of expenditure.

Robust standard errors adjusted for clustering at the country level.

In summary, the degree of market development does not seem to have a sizable impact on the political support to democracy, or on the rejection of authoritarian regimes. In contradiction with current priors, developing market institutions is not a guarantee or a sufficient condition of the subsequent emergence of democracy.

\section{Conclusion}

The main result of this paper is that in Transition countries, democracy appears to generate some popular support for the market, while economic liberalization does not clearly raise the support for democracy. These observations are consistent with the empirical observation that market economies can live without democracy, whereas there is no historical evidence of a democratic society without a market economy.

To be sure, these results only suggest that democracy raises the subjective support to the

${ }^{21}$ Here we do not use frontier-zones integration as there is no point in supposing that inhabitants of a given region experience the level of wealth of neighbour regions. 
market. This does not mean that democracy is not likely to complicate the task of reformers, with the risk of impeding market liberalization. The relation running from democracy to the support to the market is particularly strong in countries of the CIS, Central Asia and South Eastern Europe, as opposed to other countries of the European Union (e.g. Central Europe). Hence, the link seems to be particularly relevant for “developing” countries, i.e. countries which are still in an earlier stage of democratic development.

Concerning the reverse relation, our results cast doubt on the idea that democracy needs naturally emerge as a by-product of capitalism, particularly in less developed countries. The data do not support the idea that market liberalization as such is sufficient to trigger the demand for democracy; identically, citizens of countries with less developed markets do not appear to be less supportive of democracy. Hence, one cannot advocate the preferences of citizens to postpone the construction of democratic institutions.

In summary, our data do not support a widespread view concerning the optimal sequencing of reforms for developing countries: it seems that building democratic institutions can play as an ingredient in favor of market liberalization, whereas early market development is no guarantee of a later popular support to democracy.

\section{Bibliography}

Acemoglu, Daron, Simon Johnson and James A. Robinson (2001), "The Colonial Origins of Comparative Development: An Empirical Investigation”, The American Economic Review, Vol. 91, No. 5, pp. 1369-1401.

Acemoglu, Daron, Simon Johnson, James A. Robinson and Pierre Yared (2004a), "From Education to Democracy?”, American Economic Association Papers and Proceedings,

Acemoglu, Daron, Simon. Johnson, James A. Robinson and Pierre Yared (2004b), "Income and Democracy", mimeo, MIT.

Alesina, Alberto and Nicola Fuchs-Schündeln (2005), "Good bye Lenin (or not?): The Effect of Communism on People's Preferences", Harvard Institute of Economic Research Discussion Paper N²076.

Aslund, Anders, Peter Boone and Simon Johnson (2001), "Escaping the Under Reform Trap”, IMF Staff Papers, International Monetary Fund, vol. 48(4).

Babetskii, Ian, Oxana Koukhartcouk and Martin Raiser (2003), “How Deep is your 
Trade?”, EBRD working paper no. 83. 1997.

Barro, Robert (1997), Determinants of Economic Growth, Cambridge, MA: MIT Press,

Berkowitz, Daniel and John E. Jackson (2005), "The Evolution of an Economic and Political Middle Class in Transition Countries", Paper presented at the 2005 Annual Meeting of the American Political Science Association, Sept. 2005, Washington, DC.

Bertelsmann Stiftung (2005), Bertelsmann Transformation Index 2006: Political Management in International Comparison, http://www.bertelsmann-transformationindex.de/fileadmin/pdf/BTI_2006_Brosch_re_GB.pdf

Bisin, Alberto and Thierry Verdier (2000), “A Model of Cultural Transmission, Voting and Political Ideology”, European Journal of Political Economy, Elsevier, vol. 16(1), pp. 529.

Broadman, Harry (2005), "From Disintegration to Reintegration: Europe and Central Asia in International Trade”, World Bank, mimeo.

Brym Robert J. (1996), "Re-evaluating Mass Support for political and Economic Change in Russia”, Europe-Asia Studies, Vol. 48, No. 5, pp. 751-765.

Burkhart, Ross E. and Michael S. Lewis-Beck (1994), "Comparative Democracy: The Economic Development Thesis”, The American Political Science Review, Vol. 88, No. 4, pp. 903-910.

Centre for International Development and Conflict Management (CIDCM) (2006), Polity IV: Political Regimes Characteristics and Transition: 1800-2004, University of Maryland.

Citrin, Jack, Beth Reingold and Donald P. Green (1990), “American Identity and the Politics of Ethnic Change”, Journal of Politics Vol. 52, pp. 1124-54.

De Toqueville, Alexis (1839), Democracy in America, vol. 2, New York : Vintage :1945.

Dewatripont, Mathias and Gérard Roland (1992), “The Virtues of Gradualism and Legitimacy in the Transition to a Market Economy”, The Economic Journal, vol. 102(411), pp. 291-300.

Djankov, Simeon and Caroline Freund (2000), “Disintegration”, CEPR Discussion Papers 2545.

Earle, John S. and Zuzana Sakova (2000), “Business Start-ups or Disguised Unemployment? Evidence on the Character of Self-employment from Transition Economies”, Labor Economics, Vol 7, pp. 575-601.

Easton, David A. (1965), A System Analysis of Political Life, New York, London, Sydney: John Wiley \& Sons.

EBRD Transition Report (2006), Finance in transition, Chapter 1: "Progress in Transition”, pp. 1-18. 
EBRD, Life in Transition: A Survey of People’s Experiences and Attitudes (2007).

Fernandez, Raquel and Alessandra Fogli (2000), "Culture: An Empirical Investigation of Beliefs, Work, and Fertility”, NBER Working Papers 11268, National Bureau of Economic Research, Inc.

Finifter, Ada and Ellen Mickiewicz (1992), "Redefining the Political System of the USSR: Mass support for Political Change”, American political Science Review, Vol. 23, pp. 857-874.

Freedom House (2006a), Nations in Transit 2006: Democratization from Central Europe to Eurasia, Rowman and Littlefield Publishers.

Freedom House (2006b), Freedom in the World 2006: The Annual Survey of Political Rights and Civil Liberties, Rowman and Littlefield Publishers.

Giavazzi F and Guido Tabellini (2005), “Economic and Political Liberalizations”, Journal of Monetary Economics, 52, 1297-1330.

Gibson, James L. (1996), "Political and Economic Markets: Changes in the Connections Between Attitudes Toward Political Democracy and a Market Economy Within the Mass Culture of Russia and Ukraine”, The Journal of Politics, Vol. 58, No. 4, pp. 954-984.

Godoy, Sergio and Joseph Stiglitz (2006), "Growth, Initial Conditions, Law and Speed of Privatization in Transition Countries: 11 Years Later”, NBER Working Papers 11992, National Bureau of Economic Research, Inc.

Grafe, Clemens, Martin Raiser and Toshiaki Sakatsume (2005), "Beyond Borders: Reconsidering Regional Trade in Central Asia”, EBRD working paper No. 95.

Guido Tabellini (2007), “Culture and Institutions: Economic Development in the Regions of Europe », IGIER working paper.

Helliwell, John F. (1994). "Empirical Linkages between Democracy and Economic Growth”, British Journal of Political Science, Vol. 24, No. 2, pp. 225-248.

La Porta, Rafael, Florencio Lopez-de-Silanes and Andrei Shleifer ad Robert Vishny (1999), "The Quality of Goverment”, Journal of Law, Economics and Organizations, Vol. 15, pp. 222-279.

Leblang, David A. (1997), "Political Democracy and Economic Growth: Pooled CrossSectional and Time-Series Evidence”, British Journal of Political Science, Vol. 27, No. 3, pp. 453-466.

Lindlblom Charles E. (1995), "Market and Democracy. Obliquely”, Political Science and Politics, 28(4), 684-688.

Lipset, Seymour M. (1959), "Some Social Requisites of Democracy: Economic Development and Political Legitimacy”, The American Political Science Review, Vol. 53, No. 1, pp. 69-105 
Lütkepohl, Helmut (1982), “Non-causality due to omitted variables”, Journal of Econometrics, Vol. 19, Issues 2-3, pp. 367-378.

Marx, Karl (1867), Capital, Vol. 1 A Critique of Political Economy, ed. Penguin Classique London, 1990.

Mason, David S. (1995), “Attitudes Toward the Market and political Participation in the Postcommunist States”, Slavic Review, Vol. 54, No. 2, pp. 385-406.

McIntosh, Mary, Martha Abele Mac Iver, Daniel G. Abele and Dina Smeltz (1994), "Publics Meet Market Democracy in Central and Eastern Europe: 1991-1996”, Slavic Review, Vol. 53, No. 2, pp. 483-512.

Mill, John Stuart (1860). Considerations on Representative Government. In Utilitarianism, Liberty, and Representative Government, ed. H. B. Acton. London: Dent, 1951.

Miller, Arthur, Vicki L. Hesli and William M. Reisinger (1994), "Reassessing Mass Support for Political and Economic Change in the Former USSR", The American Political Science Review, Vol. 88, pp. 399-411.

Miller, Arthur, William M. Reisinger (1994) and Vicki L. Hesli (1996), “Understanding Political Change in Post-Soviet Societies: a Further Commentary on Finifter and Mickiewicz”, The American Political Science Review, Vol. 90, No. 1, pp. 153-166.

Minier, Jenny A. (2001). "Is Democracy a Normal Good? Evidence from Democratic Movements”, Southern Economic Journal, Vol. 67, No. 4, pp. 996-1009.

Mishler, William and Richard Rose (1994), "Support for Parliaments and Regimes in the Transition toward Democracy in Eastern Europe”, Legislative Studies Quarterly, Vol. 19, No. 1, pp. 5-32.

Okui, Katsuyoshi (2005), "Causality Between Political Freedom and Economic Freedom”, Otemon Gakui University Working Paper, Osaka.

Persson, Torsten and Guido Tabellini (2006), “Democracy and Development: The Devil in the Details », American Economic Review Papers and Proceedings, 96, 319-324.

Persson, Torsten and Guido Tabellini (2007a), The Growth Effects of Democracy: Is It Heterogenous and How Can It Be Estimated? May 2007, forthcoming in Institutions and Economic Performance, edited by E. Helpman , Harvard University Press.

Persson, Torsten and Guido Tabellini (2007b), "Democratic Capital: The Nexus of Political and Economic Change », IGIER working paper.

Przeworski, Adam (2004), "Democracy and Economic Development”. In Edward D. Mansfield and Richard Sisson (eds.), The Evolution of Political Knowledge. Columbus: Ohio State University Press.

Przeworski, Adam and Fernando Limongi (1993), "Political Regimes and Economic Growth”, The Journal of Economic Perspectives, Vol. 7, No. 3, pp. 51-69. 
Rodrick Dany and Wacziarg R. (2005), "Do Democratic Transitions Produce Bad Economic Outcomes?” American Economic Review Papers and Proceedings, 95, 50-56.

Roland, Gérard (2001), “The Political Economy of Transition”, The Journal of Economic Perspectives, Vol. 16, No. 1, pp. 29-50.

Roland, Gérard and Thierry Verdier (2003), "Law Enforcement and Transition”, European Economic Review, vol. 47, No. 4, pp. 669-685.

Schumpeter, Joseph A., (1942) Capitalism, Socialism and Democracy, New York, Harper and Bros.

Zhuravskaya, Ekaterina V. (2000), "Incentives to Provide Local Public Goods: Fiscal Federalism, Russian Style”, Journal of Public Economics, vol. 76, No. 3, pp. 337-368. 


\section{Annex}

\section{Table A1. Descriptive Statistics}

\section{Variable}

Market preferable

Planned economy is

preferable

Does not matter_eco

Democracy preferable

Authoritarian reg.

preferable

Does not matter_pol

old

Mid-age

Adult

gender

unemployed

White collar worker

Blue collar worker

Service worker

Farmer or farm worker

Pensioner

Student

Housewife

out of the labor force

self employed

Support democracy

Authoritarian

Does not matter

Industrial index

imp_freel

imp_laword

imp_freesp

imp_peace

imp_indeprs

imp_polopp

imp_courtin

imp_courteq

imp_minor

imp_freeab

impdemo
1 if resp. prefers market economy to other form of economic system

Mean

1 if resp. prefers planned economy under certain circumstances

1 if resp. answers "for people like me it does not matter" whether the economy is organized as a market economy or as a planned economy

1 if resp. prefers democracy to other form of political system

1 if resp. prefers authoritarian regime under certain circumstances

1 if resp. answers "for people like me it does not matter" whether a government is democratic or authoritarian

more than 65 years old

between 50 and 65 years old

between 35 and 50 years old

1 if male

actively looking for a job. waiting for an answer or find no job available

0.17

0.18

0.12

0.05

0.21

0.03

0.06

0.05

0.08

0.57

0.16

0.27

2.39

0.89

0.59

0.51

0.65

0.44

0.39

0.55

0.60

0.42

0.53

5.38
Std. dev.

0.50

0.44

0.46

0.49

0.37

0.37

0.37

0.43

0.46

0.50

0.29

0.38

0.38

0.32

0.22

0.41

0.16

0.25

0.22

0.28

0.49

0.37

0.44

1.05

0.32

0.49

0.50

0.48

0.50

0.49

0.50

0.49

0.49

0.50

3.59 
Table A2: Attitudes towards the Market and Democracy in frontier zones of adjacent countries, ranked by democracy level

\begin{tabular}{|c|c|c|c|c|}
\hline & $\begin{array}{l}\text { Country i } \\
\text { Market } \\
\text { preferable }\end{array}$ & $\begin{array}{l}\text { Country j } \\
\text { Market } \\
\text { preferable }\end{array}$ & $\begin{array}{l}\text { Country i } \\
\text { Democracy } \\
\text { preferable }\end{array}$ & $\begin{array}{l}\text { Country j } \\
\text { Democracy } \\
\text { Preferable }\end{array}$ \\
\hline Estonia $>$ Russia & 0.56 & 0.33 & 0.68 & 0.48 \\
\hline Estonia $>$ Latvia & 0.46 & 0.17 & 0.50 & 0.56 \\
\hline Russia $>$ Belarus & 0.32 & 0.48 & 0.38 & 0.57 \\
\hline Ukraine $>$ Russia & 0.50 & 0.22 & 0.61 & 0.31 \\
\hline Russia $>$ Kazakhstan & 0.28 & 0.35 & 0.42 & 0.52 \\
\hline Latvia> Lithuania & 0.32 & 0.50 & 0.51 & 0.59 \\
\hline Lithuania $>$ Belarus & 0.55 & 0.33 & 0.58 & 0.61 \\
\hline Albania> Montenegro & 0.71 & 0.51 & 0.74 & 0.74 \\
\hline Georgia $>$ Armenia & 0.45 & 0.25 & 0.62 & 0.60 \\
\hline turkey>Armenia & 0.27 & 0.20 & 1.00 & 0.50 \\
\hline Georgia > Azerbaijan & 0.35 & 0.39 & 0.50 & 0.44 \\
\hline Poland $>$ Belarus & 0.42 & 0.43 & 0.60 & 0.12 \\
\hline Ukraine $>$ Belarus & 0.55 & 0.41 & 0.58 & 0.49 \\
\hline Poland > Ukraine & 0.13 & 0.46 & 0.47 & 0.51 \\
\hline Slovak $>$ Poland & 0.27 & 0.33 & 0.59 & 0.46 \\
\hline Romania $>$ Ukraine & 0.74 & 0.82 & 0.82 & 0.87 \\
\hline Slovak Rep.>Ukraine & 0.48 & 0.50 & 0.52 & 0.51 \\
\hline Croatia $>$ Bosnia & 0.34 & 0.29 & 0.43 & 0.49 \\
\hline Slovenia $>$ Croatia & 0.55 & 0.40 & 0.70 & 0.58 \\
\hline Serbia $>$ Macedonia & 0.90 & 0.27 & 0.92 & 0.40 \\
\hline Hungary $>$ Serbia & 0.57 & 0.38 & 0.80 & 0.42 \\
\hline Bulgaria> Macedonia & 0.25 & 0.54 & 0.43 & 0.56 \\
\hline Bulgaria>Romania & 0.25 & 0.32 & 0.32 & 0.42 \\
\hline Romania > Moldova & 0.59 & 0.41 & 0.68 & 0.62 \\
\hline Romania >Serbia & 0.56 & 0.38 & 0.52 & 0.42 \\
\hline Hungary>Romania & 0.69 & 0.69 & 0.75 & 0.75 \\
\hline Hungary $>$ Croatia & 0.24 & 0.37 & 0.41 & 0.49 \\
\hline Hungary > Romania & 0.27 & 0.69 & 0.61 & 0.75 \\
\hline Slovak Rep.>Hungary & 0.58 & 0.37 & 0.73 & 0.65 \\
\hline Slovak>Czech Rep. & 0.49 & 0.41 & 0.64 & 0.40 \\
\hline Poland >Czech Rep & 0.45 & 0.48 & 0.58 & 0.62 \\
\hline Kyrgyzstan>Kazakhstan & 0.49 & 0.27 & 0.53 & 0.43 \\
\hline Kyrgyzstan>Tajikistan & 0.70 & 0.35 & 0.75 & 0.48 \\
\hline
\end{tabular}

Symbols $>$ or < indicate the country ranking in terms of democracy according to Freedom House Nations in Transit 2006. Average score inside each zone. 
Table A3: Attitudes Towards the Market and Democracy

in Frontier-Zones of Selected Countries

\begin{tabular}{|c|c|c|c|c|c|c|c|}
\hline BELARUS & $\begin{array}{l}\text { Fronteer } \\
\text { industrial } \\
\text { index }\end{array}$ & $\begin{array}{l}\text { Market } \\
\text { preferable }\end{array}$ & $\begin{array}{l}\text { Democ. } \\
\text { preferable }\end{array}$ & ROMANIA & $\begin{array}{l}\text { Fronteer } \\
\text { industrial } \\
\text { index }\end{array}$ & $\begin{array}{l}\text { Market } \\
\text { preferable }\end{array}$ & $\begin{array}{l}\text { Democ. } \\
\text { preferable }\end{array}$ \\
\hline Belarus Poland & 1.87 & 0.43 & 0.12 & Romania Serbia & 2.39 & 0.56 & 0.52 \\
\hline Belarus Ukraine & 1.89 & 0.41 & 0.49 & Romania Bulgaria & 2.43 & 0.32 & 0.42 \\
\hline Belarus Russia & 1.98 & 0.48 & 0.57 & Romania Hungary & 2.58 & 0.69 & 0.75 \\
\hline Belarus Lithuania & 2.03 & 0.33 & 0.61 & $\begin{array}{l}\text { Romania } \\
\text { Moldova }\end{array}$ & 2.64 & 0.59 & 0.68 \\
\hline CROATIA & & & & RUSSIA & & & \\
\hline Croatia Bosnia & 2.35 & 0.34 & 0.43 & Russia Mongolia & 2.2 & 0.64 & 0.61 \\
\hline Croatia Slovenia & 2.31 & 0.4 & 0.58 & $\begin{array}{l}\text { Russia } \\
\text { Kazakhstan }\end{array}$ & 2.26 & 0.28 & 0.42 \\
\hline HUNGARY & & & & Russia Estonia & 2.33 & 0.33 & 0.48 \\
\hline Hungary Slovak Rep. & 2.33 & 0.37 & 0.65 & Russia Poland & 2.33 & 0.45 & 0.57 \\
\hline Hungary Croatia & 2.38 & 0.12 & 0.34 & Russia Belarus & 2.33 & 0.32 & 0.38 \\
\hline Hungary Romania & 2.48 & 0.27 & 0.61 & Russia Ukraine & 2.51 & 0.22 & 0.31 \\
\hline Hungary Serbia & 2.53 & 0.57 & 0.8 & SERBIA & & & \\
\hline LATVIA & & & & Serbia Macedonia & 2.12 & 0.9 & 0.92 \\
\hline Latvia Lithuania & 2.9 & 0.32 & 0.51 & Serbia Romania & 2.29 & 0.39 & 0.48 \\
\hline Latvia Russia & 2.9 & 0.24 & 0.43 & Serbia Hungary & 2.4 & 0.38 & 0.42 \\
\hline Latvia Estonia & 3.38 & 0.17 & 0.56 & UKRAINE & & & \\
\hline LITHUANIA & & & & Ukraine Poland & 2.25 & 0.46 & 0.51 \\
\hline Lithuania Belarus & 2.5 & 0.55 & 0.58 & Ukraine Belarus & 2.32 & 0.55 & 0.58 \\
\hline Lithuania Latvia & 2.9 & 0.5 & 0.59 & Ukraine Russia & 2.34 & 0.5 & 0.61 \\
\hline Lithuania Russia & 3.17 & 0.26 & 0.6 & Ukraine Romania & 2.53 & 0.82 & 0.87 \\
\hline POLAND & & & & $\begin{array}{l}\text { Ukraine Slovak } \\
\text { Rep. }\end{array}$ & 2.67 & 0.5 & 0.51 \\
\hline Poland Belarus & 1.94 & 0.42 & 0.6 & & & & \\
\hline Poland Ukraine & 2.26 & 0.13 & 0.47 & & & & \\
\hline Poland Czech Rep. & 2.43 & 0.45 & 0.58 & & & & \\
\hline Poland Slovak Rep. & 2.77 & 0.33 & 0.46 & & & & \\
\hline
\end{tabular}


Table A4. Descriptive Statistics by Country

\begin{tabular}{|c|c|c|c|c|c|c|}
\hline & $\begin{array}{c}\text { Support } \\
\text { Democracy } \\
(\%)\end{array}$ & $\begin{array}{c}\text { Support } \\
\text { Authoritarian } \\
(\%)\end{array}$ & $\begin{array}{c}\text { Support } \\
\text { Market (\%) }\end{array}$ & $\begin{array}{l}\text { Support } \\
\text { Plan (\%). }\end{array}$ & $\begin{array}{c}\text { Industrial } \\
\text { Index }\end{array}$ & $\begin{array}{l}\text { Importance } \\
\text { democracy }\end{array}$ \\
\hline Albania & 66.1 & 9.4 & 65.15 & 13.14 & 2.30 & 7.23 \\
\hline Armenia & 47.01 & 13.6 & 33.22 & 22.19 & 2.32 & NA \\
\hline Azerbaijan & 47.55 & 9.13 & 39.61 & 9.27 & 1.96 & 5.15 \\
\hline Belarus & 52.04 & 17.06 & 48 & 19.08 & 1.94 & 4.33 \\
\hline Bosnia & 61.42 & 19.14 & 34.37 & 38.65 & 2.33 & 6.43 \\
\hline Bulgaria & 45.90 & 17.74 & 36.79 & 24.72 & 2.61 & 5.89 \\
\hline Croatia & 55.28 & 14.12 & 36.32 & 26.78 & 2.37 & 7.41 \\
\hline Czech Rep. & 58.53 & 17.59 & 47.03 & 27.25 & 2.60 & 5.36 \\
\hline Estonia & 61.11 & 12.23 & 49.47 & 18.45 & 2.78 & 6.03 \\
\hline FYR Macedonia & 46.63 & 18.04 & 33.88 & 28.96 & 2.33 & 5.09 \\
\hline Georgia & 58.13 & 11.63 & 38 & 23.04 & 2.28 & 5.73 \\
\hline Hungary & 61.68 & 13.45 & 37.31 & 26.29 & 2.53 & 6.17 \\
\hline Kazakhstan & 48.81 & 22.23 & 31.92 & 39.52 & 2.50 & 5.86 \\
\hline Kyrgyzstan & 58.92 & 19.11 & 49.75 & 27.68 & 2.25 & 4.35 \\
\hline Latvia & 55.97 & 19.59 & 39.11 & 26.16 & 2.75 & 5.99 \\
\hline Lithuania & 54.42 & 10.31 & 41.64 & 17.12 & 2.73 & 5.72 \\
\hline Moldova & 49.59 & 19.25 & 39.19 & 32.75 & 2.32 & 4.32 \\
\hline Mongolia & 69.92 & 19.82 & 71.42 & 16 & 2.22 & 1.79 \\
\hline Montenegro & 73.27 & 8.26 & 47.17 & 26.02 & 2.19 & 6.82 \\
\hline Poland & 54.19 & 17.49 & 40.24 & 14.6 & 2.36 & 6.27 \\
\hline Romania & 50.19 & 26.68 & 45.87 & 26.77 & 2.55 & 5.81 \\
\hline Russia & 36.05 & 32.77 & 27.67 & 41.03 & 2.37 & 4.88 \\
\hline Serbia & 51.02 & 14 & 44.52 & 21.21 & 2.33 & 6.80 \\
\hline Slovak Rep. & 67.43 & 13.21 & 47.51 & 24.57 & 2.52 & 5.12 \\
\hline Slovenia & 66.37 & 8.18 & 49.79 & 18.77 & 2.26 & 6.29 \\
\hline Tajikistan & 62.74 & 15.87 & 51.35 & 28.18 & 2.21 & 4.26 \\
\hline Turkey & 74.93 & 6.04 & 37.59 & 32.75 & 2.06 & 7.01 \\
\hline Ukraine & 55.14 & 24.45 & 42.19 & 33.24 & 2.36 & 5.39 \\
\hline Uzbekistan & 68.4 & 12.24 & 43.55 & 38.04 & 2.27 & 3.84 \\
\hline
\end{tabular}


Table A5. Indices of Democracy and Country Rankings

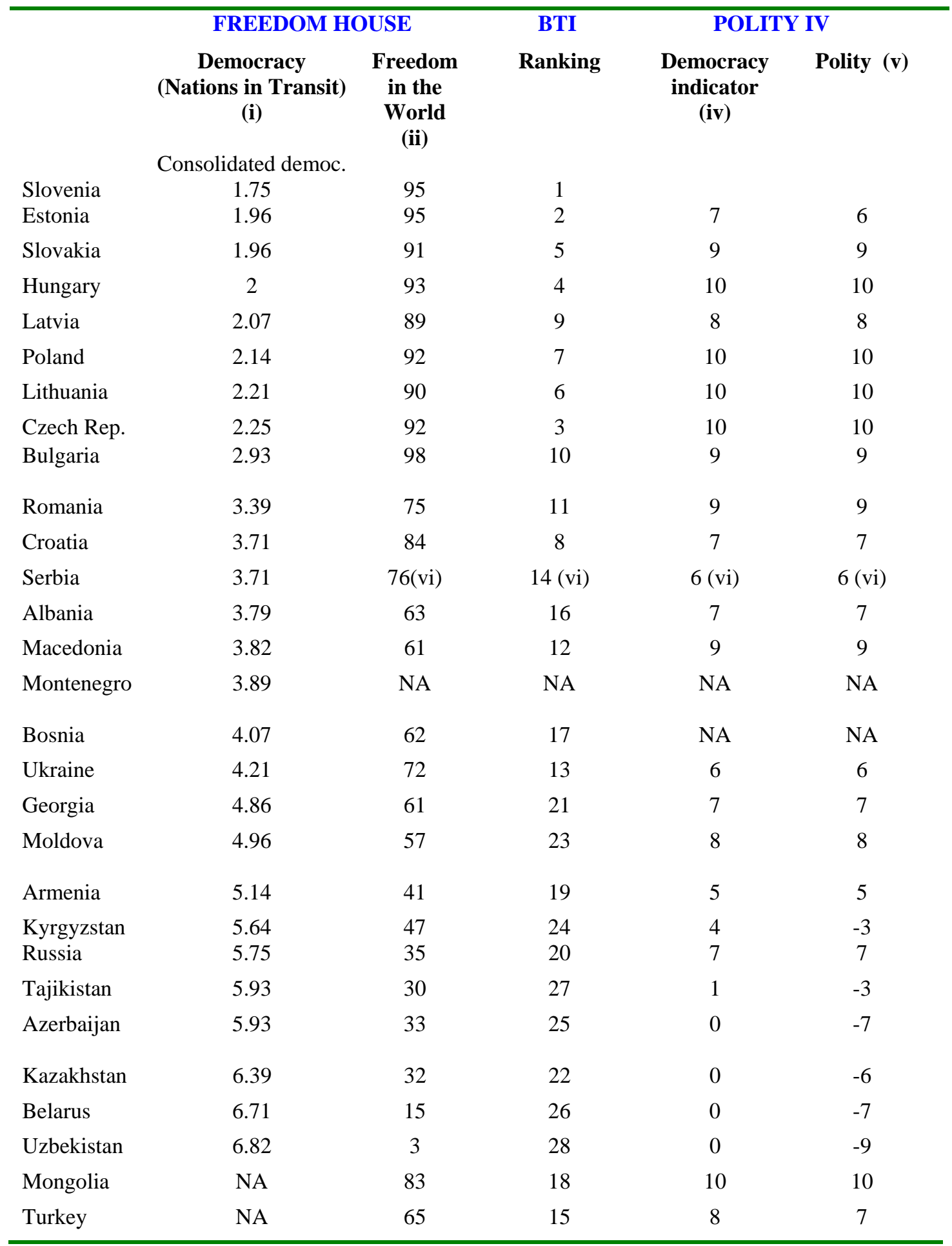


(i) The democracy score ratings from Nations in Transit survey by Freedom House are based on a scale of 1 to 7 , with 1 representing the highest level of democratic progress and 7 the lowest. The Democracy Score is an average of ratings for electoral process, civil society, independent media, independence of the judicial system, and corruption.

(ii) The Freedom in the World survey provides an annual evaluation of the state of global freedom as experienced by individuals. The ratings process is based on a checklist of 10 political rights questions and 15 civil liberties questions. The political rights questions encompass electoral process, political pluralism and participation, and functioning of the government. The civil liberties questions are concerned with freedom of expression and belief, associational and organizational rights, rule of law, and personal autonomy and individual rights. The highest number of points that can be awarded to the political rights checklist is 40 , and that to the civil liberties checklist is 60 , with the highest score indicating more freedom. This index is thus more global than the democracy index and more concerned with the actual rights and social freedoms enjoyed by individuals.

(iii) The Bertelsmann Transformation Index (BTI) is a global ranking that analyzes and evaluates development and transformation processes in 119 countries. This index is however not only concerned with democracy, but also with the development of the market economy in each country, and for that reason, is less well suited than indicators purely concerned with democracy for our identification strategy.

(iv) The Polity IV Democracy indicator is an additive eleven-point scale (0-10), which is a weighted indicator of the competitiveness of political participation, the openness and competitiveness of executive recruitment, and constraints on the chief executive.

(v) The Polity indicator from Polity IV is a combined polity score that is computed by subtracting the 'autocracy score', which indicates how restricted or suppressed political participation is, to the democracy score. A negative ranking thus signifies that autocratic characteristics of a regime outweigh its democracy characteristics.

(vi) Serbia and Montenegro are pooled. 
Table A6. Indices of Industrial Market Development at Frontier-Zones

\begin{tabular}{lcccc}
\hline Frontier-Zone i j & Frontier zone i & Country_i & Frontier zone & Country j \\
Albania Montenegro & & & $\mathbf{j}$ & \\
Armenia Georgia & 2.27 & 2.36 & 2.43 & 2.24 \\
Azerbaijan Georgia & 2.00 & 2.36 & 2.38 & 2.24 \\
Belarus Lithuania & 1.89 & 1.89 & 2.25 & 2.24 \\
Belarus Poland & 1.95 & 1.92 & 2.53 & 2.70 \\
Belarus Russia & 2.04 & 1.92 & 2.03 & 2.38 \\
Belarus Ukraine & 2.00 & 1.92 & 2.00 & 2.38 \\
Bosnia Croatia & 2.14 & 1.92 & 2.21 & 2.33 \\
Bosnia Serbia & 2.42 & 2.38 & 2.38 & 2.37 \\
Bulgaria Macedonia & 2.56 & 2.38 & 2.12 & 2.25 \\
Croatia Bosnia & 2.47 & 2.62 & 2.18 & 2.29 \\
Croatia Slovenia & 2.38 & 2.37 & 2.42 & 2.38 \\
Czech Poland & 2.31 & 2.37 & 2.19 & 2.25 \\
Czech Slovakia & 2.62 & 2.61 & 2.26 & 2.38 \\
Estonia Russia & 2.80 & 2.61 & 2.28 & 2.49 \\
Estonia Latvia & 2.34 & 2.74 & 2.55 & 2.38 \\
Kazakh-Kyrgyzstan & 3.14 & 2.33 & 2.27 & 2.80 \\
Kazakhstan Russia & 2.65 & 2.48 & 2.32 & 2.25 \\
Kyrgyzstan Tajikistan & 2.57 & 2.48 & 2.38 & 2.38 \\
Latvia Lithuania & 2.00 & 2.25 & 2.55 & 2.20 \\
Macedonia Serbia & 2.91 & 2.80 & 2.96 & 2.70 \\
Moldova Romania & 2.35 & 2.29 & 2.50 & 2.25 \\
Poland Slovakia & 2.58 & 2.26 & 2.93 & 2.56 \\
Poland Ukraine & 2.27 & 2.38 & 2.55 & 2.49 \\
Romania Serbia & 2.53 & 2.38 & 3.14 & 2.33 \\
Russia Ukraine & 2.47 & 2.56 & 2.29 & 2.25 \\
Slovakia Ukraine & 3.00 & 2.38 & 2.40 & 2.33 \\
\hline & & 2.49 & 2.67 & 2.33 \\
\hline
\end{tabular}

